Secuencia (2005), 61, enero-abril, 99-142

ISSN: 0186-0348, ISSN electrónico: 2395-8464

DOI: http://dx.doi.org/10.18234/secuencia.v0i61.897

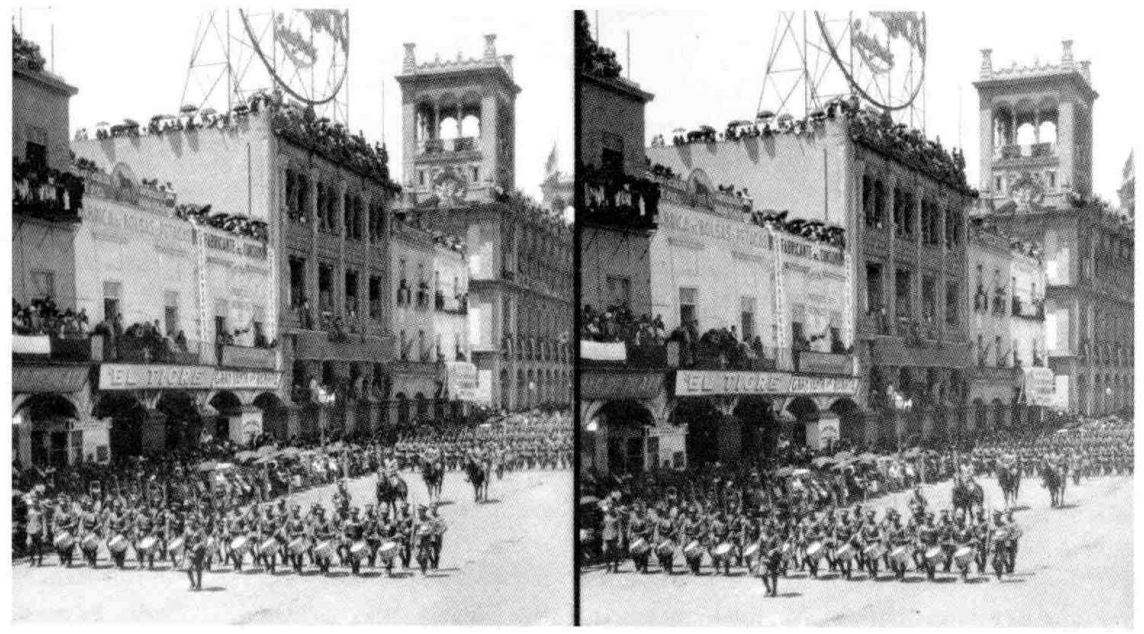




\section{Alberto Lettieri}

Doctor por la Universidad de Buenos Aires, Área Historia. Investigador del Instituto de Historia Argentina y Americana Dr. E. Ravignani, Universidad de Buenos Aires, Conicet; profesor titular regular de Historia Social General (Facultad de Ciencias Sociales-TLBA) y de Historia de los Sistemas Políticos (Facultad de Filosofía y Letras-UBA). Ha publicado artículos en las principales revistas y colecciones internacionales, y entre sus libros se cuentan: Seis lecciones de política, Prometeo, 2004; La civilización en debate. Historia contemporánea de las revoluciones burguesas al neoliberalismo, Eudeba, 2003 y Prometeo, 2004; La vida política. Armas, votos y vaces en la Argentina del siglo XIX, FCE, 2003 (con Hilda Sabato); Los tiempos modernos, Ediciones del Signo, 2001; La Repuiblica de las Instituciones. Argentina, 1852-1880, El Quijote, 2000; La República de la Opinión, Biblos, 1999 , y Vicente Fidel Lopez, Biblos, 1995.

\section{Resumen}

A partir de la caída de Rosas, en 1852 , la provincia de Buenos Aires perdió momentáneamente la hegemonía nacional. La nueva constelación política reconoció como eje al general Urquiza. Este cambio no fue aceptado por la dirigencia porteña, remisa a tolerar un liderazgo externo, que para evitarlo tramó una inédita alianza entre los políticos que en el pasado habían militado en el rosismo, y sus tradicionales adversarios liberales, retornados luego de un extenso exilio. Esta coalición adquirió el control de la urbe porteña y consiguió instrumentar un original régimen político colegiado, que exigió un sólido consenso social para afrontar la pretensión de Urquiza y sus seguidores de recuperar la plaza rebelde. Durante los años de la secesión porteña, la prensa política desempeñó un papel fundamental en la formación y articulación de una sólida opinión pública que respaldó decididamente al nuevo orden político, el cual, finalmente, consiguió recuperar la hegemonía bonaerense a partir de 1861 .

Palabras clave:

Prensa política, opinión pública, Buenos Aires, Argentina, siglo XIX, Juan Manuel de Rosas.

\section{Abstract}

Following the fall of Rosas in 1852, the province of Buenos Aires momentarily lost its national hegemony. The new political constellation recognized General Urquiza as their leader. This change was not accepted by the Buenos Aires leaders, who were reluctant to accept outside rule. In order to prevent the latter, they hatched an unprecedented alliance between politicians that had opposed Rosas in the past and their traditional Liberal adversaries who had returned after a lengthy exile. This coalition acquired control over the city of Buenos Aires and managed to implement an original collegiate regime that required a solid social consensus to cope with the attempts by Urquiza and his followers to recover the rebellious area. During the years of the Buenos Aires secession, the political press played a key role in the formation and coordination of a solid public opinion that strongly supported the new political order that eventually managed to restore Buenos Aires' hegemony in 1861.

Key words:

Political press, public opinion, Buenos Aires, Argentina, Juan Manuel de Rosas.

Fecha de recepción: marzo de 2004

Fecha de aceptación: agosto de 2004 


\title{
La prensa republicana en Buenos Aires: de Caseros a Pavón (1852-1861)
}

\author{
Alberto Lettieri
}

\section{INTRODUCCIÓN}

\section{La república de la opinión}

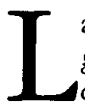

a Revolución de Mayo de 1810 exigió la construcción de un nuevo orden político en Río de la Plata, que sólo pudo configurarse a través de un complejo proceso, que se extendió durante más de medio siglo. En el caso argentino, las primeras dos décadas de vida independiente cobijaron un conjunto de experiencias fallidas, guerras civiles y conflictos externos, que derivaron finalmente en la creación de un régimen confederal bastante sólido, aunque escasamente institucionalizado, diseñado por el caudillo bonaerense Juan Manuel de Rosas. El agotamiento de esta experiencia, clausurada con la derrota de Caseros, en 1852, permitió redefinir un complejo tablero político, donde las miras y expectativas comunes de los vencedores no iban mucho más allá del objetivo ya cumplido de derrocar al gobernador porteño. De este modo, por debajo de la aceptación de la necesidad de organizar al país bajo un régimen político institucionalizado a través de la sanción de una constitución nacional, subyacía una manifiesta disputa por la conducción política. ${ }^{1}$

\footnotetext{
${ }^{1}$ Véase un estudio detallado de este proceso en Lettieri, "República", 1999.
}

En la primera línea de pretendientes a la sucesión se inscribía el gobernador de la provincia de Entre Ríos, Justo José de Urquiza, quien después de un largo desempeño como primera espada del rosismo, en 1851 decidió modificar drásticamente esa lealtad, para organizar y conducir a las tropas del Ejército Grande que sellaron su final, heredando el respaldo de los caudillos del interior que habían secundado de manera consecuente al gobernante depuesto. En una segunda línea de expectativas se encontraba la elite liberal porteña, que luego de afrontar la prueba del exilio durante más de una década, se aprestaba a reasumir la dirección de la nueva etapa histórica. Dentro de este grupo, una de sus facciones, encabezada por el líder de los exiliados argentinos en Montevideo, Valentín Alsina -tras de quien se encolumnaban otros brillantes repatriados, como por ejemplo Bartolomé Mitre o Domingo F. Sarmiento-, aspiraba a detentar tanto la conducción política como ideológica, retomando en un principio el control de la provincia de Buenos Aires, para lanzar desde allí su proyecto de unificación nacional; un segundo grupo, compuesto por otros exponentes no menos brillantes del liberalismo, como Juan Bautista Alberdi o Vicente Fidel López, se contentaba con alcanzar el objetivo más modesto e instrumental de imponer los nuevos rumbos ideológicos y el nuevo 
proyecto nacional a través de la sólida autoridad que en un principio detentaba Urquiza. Finalmente, dentro del antiguo rosismo porteño se produjo una escisión: mientras las antiguas jefaturas militares aceptaron encolumnarse obedientemente tras de Urquiza, los políticos urbanos establecieron su alianza con éste y la alteraron con otra, no menos significativa, con sus tradicionales enemigos liberales, en el marco de un intento desesperado por continuar desempeñando un papel destacado en la escena política bonaerense tras el alejamiento de Rosas.

Aun cuando en un primer momento Urquiza pareció encolumnarse hacia un liderazgo incuestionado, las energías aplicadas a resolver la organización institucional de la nación implicaron un cierto descuido del frente porteño, que posibilitó la consolidación de ciertas tendencias autonómicas, manifestadas durante las Jornadas de Junio de 1852 -ocasión en que el alejamiento momentáneo de Urquiza de la ciudad posibilitó la concreción de una especie de rebelión legislativa contra las autoridades provinciales que le respondian-, para consagrarse finalmente el 11 de septiembre de 1852, cuando una revolución apoyada simultáneamente por liberales y ex rosistas recuperó el control de la ciudad de Buenos Aires. Por más que Urquiza y sus aliados intentaron recuperar la plaza, sus esfuerzos fueron vanos: a mediados de 1853 , la secesión de Buenos Aires era ya un hecho. Para mediados de 1854, no solamente dos estados, uno provincial y otro confederal se repartían el territorio nacional, sino que cada uno de ellos había institucionalizado su régimen a través de una constitución que proclamaba su soberanía indisputada. De este modo, la caída de
Rosas no posibilitó una inmediata organización de la nación, sino un retroceso muy evidente en la consecución de un orden estable, como sí en cambio había garantizado el caudillo porteño. Por el contrario, la década transcurrida entre 1852 y 1861 fue el escenario de un conflicto latente entre ambas entidades estatales, que se tradujo en enfrentamientos ocasionales y dos batallas muy significativas: la de Cepeda, en 1859, donde las fuerzas de la Confederación demostraron tanto su superioridad en el terreno de las armas cuanto su incapacidad para explotar a posteriori las posibilidades que les otorgaba la victoria, y la de Pavón, en 1861, cuando el triunfo de los porteños posibilitó la construcción de un nuevo régimen nacional, bajo la hegemonía porteña. ${ }^{2}$

La secesión bonaerense, siempre amenazada por las fuerzas leales a Urquiza, exigió la celebración de una alianza entre los políticos liberales y rosistas, antiguos adversarios pero ahora hermanados en su pretensión común de reconstruir la hegemonía porteña nacional o, cuando menos, de imposibilitar la consagración de cualquier otra que significara el traslado del centro de gravedad político hacia otras regiones del territorio nacional. Su resultado fue la construcción de un régimen colegiado, articulado en torno a la Sala de Representantes porteña, que recurrió constantemente a la negociación de cúpulas y al tramado de un sólido consenso social, por medio de un conjunto de tácticas y prácticas características que incluyeron tanto la frecuente convocatoria a movilizaciones públicas, cuanto la interpelación constante de las numerosas aso-

\footnotetext{
${ }^{2}$ Lettieri, Reppiblica, 2000, “Introducción” y cap. 1.
} 
ciaciones y grupos de interés que no tardaron en multiplicarse en la ciudad, dando vida a una activa esfera pública en clave burguesa. Si bien los representantes eran escogidos por medio de un sistema electoral bastante elaborado, caracterizado por la ingeniosa tecnología desplegada por las facciones en la elaboración del fraude, este régimen siempre reconoció en la opinión pública una de sus fuentes principales de legitimación, a punto tal que resulta posible caracterizarlo como una verdadera república de la opinión. ${ }^{3} \mathrm{La}$ alianza entre liberales y ex rosistas mantuvo su vigor entre 1852 y 1856 , para comenzar a decaer a partir de entonces, en la medida en que algunos signos de agotamiento en la disposición de la Confederación para recuperar el control sobre la urbe posibilitaron el inicio de graves disputas internas por el liderazgo político, que retrotrajeron la relación entre ambos grupos a la existente en tiempos de Rosas.

\section{La prensa republicana: una aproximación inicial}

En el contexto de la república de la opinión -y al menos para el periodo que se extiende hasta 1880-, la prensa periódica desempeñó un papel fundamental en la difusión de un conjunto de valores, prácticas e ideas, que sentaron las bases de un nuevo consenso republicano y liberal, asentado sobre valores tales como la libertad, el individualismo, la propiedad y la participación pública, que vino a reemplazar a la articulación social previa que estalló con la caída de Rosas. Por enton-

${ }^{3}$ Lettieri, "República", 1999. ces, la actividad periodística experimentó una verdadera explosión, multiplicándose las publicaciones. Si bien la crítica y el debate periodísticos gozaron de un continuado florecimiento, el carácter instrumental que las elites que encabezaron el proceso de construcción de un nuevo Estado Nacional y un nuevo régimen político asignaron a la prensa escrita, en la búsqueda de obtener un consenso significativo, parece haber impuesto su sello sobre la actividad periodística, que habría quedado subordinada a las reglas del juego político. Pese a que esta lectura es casi un lugar común dentro de la literatura existente, numerosos autores han sostenido que esto no habría afectado la vigencia de una notable libertad de expresión.

Esta interpretación, sin embargo, parece contradecirse con las características que asumieron la prensa y la actividad periodística en Buenos Aires en la década que siguió a la caída de Juan Manuel de Rosas. En efecto, la importancia asignada a la prensa en el proceso de formación de la opinión pública por la nueva elite colegiada que asumió por entonces la conducción provincial -expresión de una novedosa alianza entre liberales retornados y políticos rosistas, bendecida por las clases propietarias y los sectores medios urbanos en proceso de crecimiento-, parece haber afectado gravemente la vigencia de la libertad de prensa. En efecto, numerosos indicios permiten suponer que, condicionados por la imposición de una legislación que penaba severamente los "excesos" en el ejercicio de la actividad periodística y expuestos a una dependencia significativa respecto de la obtención de subsidios oficiales, los periódicos habrían gozado de estrechos márgenes de acción, subordinados a la evolución del 
equilibrio político provincial y nacional, lo que le habría exigido adoptar una matriz indudablemente política. De todos modos, estas observaciones provisorias no constituyen una negación de la existencia de un sostenido florecimiento de la crítica o del debate periodísticos, aun cuando a menudo éstos parecen haber expresado tomas de posición particulares sobre cuestiones de actualidad dentro de los límites del consenso básico existente, o bien se limitaron a traducir rencillas y rivalidades personales o grupales. Pese a ello, la prensa alcanzó picos de elevada calidad retórica, aplicada a la formación de una opinión pública remozada, apuntalada sobre una nueva racionalidad definida en clave republicana y liberal.

En este artículo me propongo estudiar la prensa porteña en la década de 1850 . En la primera parte, analizaré las características generales de un género propio de la segunda mitad del siglo XIX en Argentina: el periodismo político. Para ello, examinaré su vinculación con la política facciosa, las funciones desempeñadas dentro del proceso de creación estatal, sus relaciones con la sociedad civil y su contribución a la construcción del sistema de legitimación republicano. En la segunda parte estudiaré la cuestión de la libertad de imprenta, en relación con la problemática más general de las posibilidades y los límites establecidos para el ejercicio del disenso entre Caseros y la batalla de Pavón. Finalmente, vincularé mi análisis con la pretensión del Estado provincial de incidir en la configuración y articulación de la sociedad civil, la cual ya contaba con una larga tradición en Río de la Plata.
LA PRENSA POLÍtica DE Buenos Aires EN LA SEGUNDA MITAD DEL SIGLO XIX

\section{Características de la prensa política}

La actividad periodística alcanzó un gran desarrollo en Buenos Aires después de Caseros. En 1855, el Almanaque comercial y guía de forasteros para el Estado de Buenos Aires consignaba la existencia de once librerías, diez imprentas y dos litografías, cifra que según el Registro de la actividad impresora y editorial de la ciudad se incrementó para 1859 a quince librerías, doce imprentas y dos litografías. ${ }^{4}$ Según Guillermo Furlong, los cuatro diarios bonaerenses de mayor envergadura, entre $\mathrm{Ca}-$ seros y Pavón, fueron El Nacional (18521899), Los Debates (1852-1858), La Tribuna (1853-1884) y El Orden (1855$1858){ }^{5}$ Ciertamente, no fueron los únicos. En 1852 aparecieron 30 nuevas publicaciones, 25 en 1853 , quince en 1854 , 17 en 1855,22 en 1856,18 en 1857 , quince en 1858, 17 en 1859 , trece en 1860 y 31 en 1861 . La mayor parte de estas empresas, sin embargo, no alcanzó el año de duración.

Si bien es posible contabilizar algunas publicaciones correspondientes a las colectividades inglesa, alemana y francesa, y puntuales emprendimientos culturales como, por ejemplo, La Revista del Plata -que llegó a publicar un prospecto y 23 entregas-, la inmensa mayoría de estas publicaciones corresponden al género que

${ }^{4}$ Eujenian, "Cultura", 1999, p. 195.

s Furlong, "Periodismo", 1966, vol. II, p. 195. En realidad, el periódico Las Debates fue publicado en 1852, y clausurado durante las Jornadas de Junio, para reaparecer en 1857. Véase Abad, Historia, 1965, pp. 47 y ss. 
podía llegar a otorgar, en algunos casos, prestigio y popularidad, la gravitación política de los actores que provenían del ámbito periodístico nunca consiguió aproximarse a la que retuvieron las figuras centrales de la política facciosa.

La contracara de este fallido camino que iba de la prensa a la pólítica estaba constituida por las "principales personas políticas e intelectuales del país", ${ }^{14}$ que diariamente se expresaban a través de los periódicos. En efecto, debido a su estrecha subordinación respecto del juego faccioso, el periodismo político no revistió mayor autonomía durante el periodo estudiado. Más aún, es posible afirmar que la prensa fue uno de los escenarios fundamentales de ese juego faccioso, a punto tal que el contenido de estos periódicos estaba destinado a un público compuesto fundamentalmente por los redactores de la oposición y los simpatizantes partidarios. Por ese motivo, no es de extrañar que los principales jefes políticos -como Mitre o Sarmiento- hayan dedicado muchos de sus esfuerzos a la edición de periódicos, siendo ellos mismos grandes redactores, o bien supervisando estrechamente las opiniones vertidas en sus páginas. Este control era, en algunos casos, tan cercano, que los espacios de la privacidad y del trabajo no estaban diferenciados. Al respecto, Julio Ramos apunta que Mitre editó La Nación en su propia casa hasta 1885 , y evitó cualquier tipo de división de tareas, desempeñándose simultáneamente como gerente, redactor y supervisor. ${ }^{15}$

Para Alonso, esta participación no sólo era el producto de la cultura política local, sino también de una exigencia de redac-

\footnotetext{
${ }^{14}$ Navarro, Anuario, 1897 , p. 7.

${ }^{15}$ Ramos, Desencuentros, 1989, pp. 98-99.
}

ción de largos editoriales que caracterizó a los periódicos políticos. ${ }^{16}$ En efecto, al señalar la desgastante necesidad de publicar largas columnas de opinión varias veces a la semana, Halperin Donghi concluye en que la principal habilidad del redactor residía en su capacidad para engarzar unidades formularias reiterativas para decir las mismas cosas, que tenían para el lector el sabor del lugar común. ${ }^{17}$ Este particular recurso -sello común entre los redactores de la época, que Sarmiento consiguió evitar gracias a su original sentido del estilo y que Mitre cultivó con indisputable habilidad-, al que Halperin se niega a evaluar con una connotación peyorativa, habría permitido ocultar la presentación de propuestas originales bajo el barniz de una lealtad a la herencia común de ideas y pasiones a los que el periodista interpelaba, frente a un público y un juego político poco propensos a la innovación o al enriquecimiento ideológico.

La necesidad de los redactores de mantenerse ligados a una tradición $-\mathrm{y}$, por ende, de justificar cualquier innovación como una decantación natural del universo ideológico y político que ella representaba-, era deudora de la urgencia de renovar el vínculo político y simbólico que unía al periódico con sus fieles lectores. Según Navarro Viola, en Buenos Aires "nadie leía sino el periódico destinado a la defensa de sus propias ideas políticas". Los periodistas no contaban como virtudes la "imparcialidad" o la "objetividad", ya que se esperaba de ellos la defensa a rajatabla de una causa determinada. ${ }^{18}$ Los redactores de la prensa polí-

\footnotetext{
${ }^{16}$ Alonso, "Primavera", 1997, pp. 42-43.

${ }_{17}$ Halperin, José, 1987, pp. 146-147.

${ }^{18}$ Duncan, "Prensa", 1980, p. 762.
} 
tica eran protagonistas destacados de la vida política porteña, caracterizados por la parcialidad y la arbitrariedad en sus juicios. Según Duncan, quien acometía la defensa de argumentos ajenos era acusado de ejercer una especie de "prostitución".

Los diarios políticos existían fundamentalmente para participar del debate político. Si bien la posesión de una pluma privilegiada parece haber constituido un crédito adicional para el periódico, en modo alguno era lo decisivo, ya que lo que realmente importaba era la habilidad política de los escritores. Su público principal estaba compuesto por los redactores de la oposición y sus propios simpatizantes, a quienes la lectura de los editoriales permitía renovar diariamente las solidaridades facciosas. En un clásico trabajo publicado en 1883, Ernesto Quesada señalaba: "La gran masa de la población argentina acepta aún como evangelio lo que le llega cada mañana en forma negra sobre blanco. Leído el diario, cada partidista tiene ya su opinión formada, y considera asunto de honor sostenerla a todo trance." 19

Sin embargo, no parece haber sido éste su único público. Alonso señala que, aun cuando no exhortaban regularmente a los hombres privados a abrazar la causa partidaria, en los dos meses que llevaban las campañas electorales los periódicos modificaban su discurso, tratando de convencer al electorado de abandonar la apatía y votar por el partido. ${ }^{20}$ Durante las campañas aparecían nuevos diarios de vida efímera. Una vez pasada la elección todo volvía a la normalidad.

19 Quesada, "Periodismo", 1883.

20 Alonso, "Primavera", 1997, p. 46.
Junto con las columnas de opinión -que ocupaban una porción significativa de las columnas de los periódicos-, la prensa política incluía en sus páginas otras especies -folletines, noticias sobre duelos y chismes-, que no sólo interesaban a sus conmilitones, ya que parecen haberle granjeado el acceso a un público más amplio respecto del cual contamos con conocimientos bastante limitados. Esto es, por lo menos, lo que se desprende de las afirmaciones de sus contemporáneos, quienes afirmaron reiteradamente que una literatura de escasa calidad podría contribuir a un fin noble, operando como puerta de ingreso a la lectura para un público analfabeto y bárbaro en sus hábitos. ${ }^{21}$ Pese a que algunos autores han afirmado que el público de estos periódicos era numeroso, son todavía muy escasos los datos cuantitativos disponibles sobre tiraje, suscripciones o público lector que permitan avanzar en el conocimiento de la empresa de la prensa. ${ }^{22}$

\section{La prensa política y su función estatal: la construcción de la república}

Según afirma Julio Ramos, ${ }^{23}$ entre las décadas de 1820 y 1880 el periodismo lati-

${ }^{21}$ Véase Lettieri, Formación, 1995, p. 22.

${ }^{22}$ González, Civilidad, 2002, p. 160. La estimación más confiable de la época en términos cuantitativos, aunque excede largamente el periodo que me ocupa, es la de Ernesto Quesada en su trabajo citado, quien calculaba que para 1882 circulaba un periódico por cada 13509 habitantes, sobre una población total cercana a los 3026000 habitantes. Por entonces se editaban en Buenos Aires cerca de 100 periódicos; 30 de ellos eran diarios que tiraban un total de 45000 ejemplares diarios. Quesada: "Periodismo", 1883.

${ }^{23}$ Ramos, Desencuentros, 1989, p. 92. 
noamericano fue el lugar de formalización de la polis, de la vida pública en vías de racionalización. Ramos señala que, en el marco del sistema vigente de República de las Letras, el periodismo fue el lugar encargado de consagrar la "racionalidad", la "ilustración" y la "cultura" que permitían diferenciar la "civilización" de la "barbarie". A su juicio, la escritura periodística -y no la literatura, que por entonces carecía de autonomía- permitió definir el modelo de una vida pública racionalizada, en su disposición ordenada del sentido, desempeñando un papel decisivo en la producción de una imagen de la "nacionalidad", o-en términos de Benedict Anderson-, de una "comunidad imaginada", ${ }^{24}$ al producir un público en el cual se basaron, inicialmente, las imágenes de la nación emergente. De este modo, el periódico no sólo habría permitido consolidar el mercado, sino que también contribuyó decisivamente a la producción de un campo de identidad, un sujeto nacional, inseparable en un principio del público lector, razón por la cual la prensa constituyó una matriz de los nuevos sujetos nacionales. ${ }^{25}$

${ }^{24}$ Recuérdese que Anderson enfatiza la importancia de la escritura para la regulación y delimitación del espacio nacional en su historia de la formación de los sujetos nacionales. Anderson, Imagined, 1983.

${ }^{25}$ El primer número de Los Debates, publicado el 1 de abril de 1852, incluyó en su profesión de fe, como epígrafe, la siguiente frase de Lamartine: "Cada época tiene una pasión, que la caracteriza y la domina: condición de vida si llega a ser bien comprendi$\mathrm{da}$, condición de muerte, si es desconocida. La gran pasión de nuestros tiempos es la pasión del porvenir; es la pasión de la perfectibilidad social. El instrumento de esta pasión de actualidad del mundo moral es la prensa, primer instrumento de civilización en estos días. La prensa ha salido del dominio de la legislación, ha dejado de ser un derecho político, y se ha converti-
Para el caso argentino, Duncan ha señalado que la verdadera tarea de la dirigencia en la segunda mitad del siglo XIX fue la formación del hombre republicano responsable y civilizado, emprendimiento en el cual la prensa habría desempeñado un papel esencial.

Según Ramos, el periodismo de mediados de siglo asumió una función político-estatal, desempeñando un papel primordial en la difusión del nuevo universo ideológico y de la modernización social, tareas que le exigieron asumir posiciones políticas $y$, frecuentemente, directamente partidarias. ${ }^{26}$ Esta función político-estatal -cuyo ejemplo más acabado es, seguramente, La Nación Argentina-, demandó que los periódicos se ungiesen como órganos cuasi oficiales de partidos y círculos, lo que postergó por varias décadas el surgimiento de una prensa independiente o autónoma del Estado. En efecto, los periódicos de la época fueron interpelados regularmente por las instituciones del campo político, y sus redactores -que, a menudo, compartían esta tarea con su desempeño como legisladores o funcionarios- se vieron obligados a dar cuenta de sus afirmaciones periodísticas en los ámbitos de ejercicio de sus funciones institucionales provinciales o nacionales, ${ }^{27}$ lo cual relativizó aún más la autonomía y especificidad del género periodístico. ${ }^{28}$

do en una nueva facultad, en un nuevo sentido, en una nueva fuerza orgánica del género humano, su única palanca para obrar sobre sí mismo."

${ }^{26}$ Ramos, Desencuentros, 1989, pp. 94-95.

${ }^{27}$ Lettieri, Vicente, 1995, 2a. parte.

${ }^{28} \mathrm{Si}$ bien en 1870 , con la fundación de $\mathrm{La} \mathrm{Na}$ ción, Mitre intentó iniciar una prensa independiente del Estado, el nuevo periódico no consiguió eludir inmediatamente su función política y partidista. 
El periódico político no se limitó a definir un orden racional entre sus lectores urbanos, sino que también permitió extenderlo a las zonas insubordinadas de la "barbarie". Para Ramos, la conversión del bárbaro en lector, sometiendo su oralidad a la ley de la escritura - proyecto acuñado por Bello y Sarmiento-, permitió ordenar y generar un espacio nacional, y ofició como un dispositivo pedagógico fundamental para la formación de la ciudadanía. ${ }^{29}$ En este proceso de incorporación del otro a un modelo de racionalización definido por el proyecto civilizado, habría desempeñado un papel esencial el mediador, especie de educador que leía el periódico para la comunidad analfabeta. Para González Bernaldo, la difusión de la prensa escrita en el medio popular revela tanto el desarrollo de una esfera pública donde los hombres de pluma tienen su poder, cuanto la difusión de un nuevo sentimiento de pertenencia comunitaria, operando un proceso de aculturación política que permitió la identificación con los nuevos valores colectivos difundidos por los formadores de opinión. ${ }^{30}$

Ciertamente logró un grado de autonomía mayor, desempeñando nuevas funciones sociales vinculadas a la información comercial, en el marco de un proceso de "modernización progresiva". Ramos, Desencuentros, 1989, pp. 99-100. Por su parte, Duncan señala que, cuanto menos hasta el siglo $\mathrm{xx}$, la prensa política no dejaría de desempeñar esta función estatal. Duncan, "Prensa", 1980, p. 179.

${ }^{29}$ Ramos, Desencuentros, 1989, p. 93.

${ }^{30}$ González, Civilidad, 2000, p. 169. Asimismo, la autora señala que este recurso había sido utilizado ya por Rosas para construir su régimen autoritario. Ramos coincide, señalando que el proceso se extendió de Hidalgo a Hernández. Ramos, Desencuentros, 1989, p. 93.
Durante la época, la prensa escrita no fue, ciertamente, el único medio de comunicación, ya que debió coexistir con otros géneros impresos, como el pasquín, y también con algunas voces orales, como la payada, el rumor o las noticias comunicadas de boca a boca, que todavía sobrevivían. ${ }^{31}$ Ramos destaca para el caso argentino la importancia decisiva del poema gauchesco -poesía producida por letrados para un público de iletrados-, que habría oficiado como un verdadero periódico de iletrados, que interpelaba a los bárbaros para insertarlos dentro del modelo de racionalización que proponía el proyecto civilizador. $^{32}$

\section{Prensa, política y opinión pública}

Los periódicos de la época liberal desempeñaron un papel esencial en la producción del nuevo consenso político, a partir del proceso que decantó en las Jornadas de Junio de 1852 -primera expresión de rebeldía porteña frente al poder de Urquiza, liderado por la Sala de Representantes de Buenos Aires- contribuyendo decisivamente en la construcción de un nuevo discurso de la legitimidad, articulado alrededor de la noción de opinión pública. ${ }^{33}$ En su análisis sobre la política y la prensa latinoamericanas de la época, Ramos intenta establecer un indicador sociológico sobre el agente social que determinaba este consenso, señalando que no se trataba del conjunto de la sociedad, sino de quie-

${ }^{31}$ González, Civilidad, 2000, p. 160.

${ }^{32}$ Ramos, Desencuentros, 1989, p. 93.

${ }^{33}$ Véase Lettieri, Repíblica, 1999, cap. 2. Para un estudio general de esta cuestión véase Lettieri, Civilización, 2003-2004, 1a. parte. 
nes ejercían su raciocinio en los espacios de discusión -como la propia prensa o los clubes. ${ }^{34}$ Por su parte, González Bernaldo lo identifica con los miembros de las asociaciones socioculturales, destacando su interés por participar en el proceso de una opinión consensuada, lo cual regularmente se traducía en la edición de un periódico o diario literario. ${ }^{35}$ Duncan evita ofrecer algún indicador preciso de esta opinión pública, señalando que el concepto permitía designar "algo muy diferente de las medidas cuantitativas actuales", y que constituía un antónimo de la "turba" o "el público" en general. ${ }^{36}$ Tanto Ramos como González Bernaldo concluyen su caracterización señalando que este tipo de consenso resultó característica de una particular forma de ejercicio del poder, que, en tanto reclamaba el acuerdo de ciertos grupos sociales, simultáneamente excluía o "aplastaba" a otros.

$\mathrm{El}$ análisis de Duncan, en cambio, encuentra ciertas dificultades para establecer una relación entre la opinión pública y la prensa periódica. En un principio, afirma que la política argentina no fue una simple escaramuza por el poder, sino el camino de realización de la idea republicana, subrayando acertadamente que la prensa habría desempeñado un papel esencial en ese proceso. Para demostrarlo,

${ }^{34}$ Ramos, Desencuentros, 1989, pp. 99-100.

${ }^{35}$ Según González Bernaldo, esos "espacios de opinión" constituían lazos de sociabilidad. González, Civilidad, 2000, p. 161. Para Guerra, la transmisión de la opinión durante el siglo XIX fue un "arte colectivo", que se hacía tanto a través de la lectura de la prensa escrita -en aquellos lugares donde el costo de la suscripción restringía para muchos la posibilidad de acceso-, cuanto a través de la transmisión de opiniones orales. Guerra, "Hacia", 1989.

${ }^{36}$ Duncan, "Prensa", 1980, p. 783. llama la atención sobre la naturalidad con la que los principales políticos se dedicaban a la publicación de sus respectivos diarios, lo que es presentado como un argumento terminante de su valoración de la opinión pública, a cuyo juicio se sometían voluntariamente. A continuación, se pregunta si esa opinión pública habrá significado efectivamente un control frente al ansia de poder, según lo exigido por las tendencias idealistas del pensamiento argentino.

La respuesta que elabora Duncan frente a esta interrogante es un tanto endeble, y fundamentalmente retórica. En principio, afirma que la incorporación de un cuerpo de opinión en el marco del proceso de construcción de la república de la segunda mitad del siglo XIX resultaba indispensable, aunque no fuese para desterrar la sensación de inseguridad legada por los tiempos de la barbarie. En ese contexto, agrega, la existencia de una prensa libre - de cuya existencia ofrece como única prueba la constatación de la posibilidad que habría existido por entonces de publicar lo que actualmente sería considerado como calumnia o libelo- habría tenido un valor simbólico, al asegurar la práctica cotidiana de una opinión pública que, si bien no era indispensable para el gobierno, sí lo era para la existencia de la república democrática. Para comprobarlo, rescata algunos documentos oficiales que afirman que la opinión pública era considerada por sus contemporáneos como la cuarta fuerza del Estado y que la prensa gozaba de un amplio grado de libertad. Finalmente, concluye asignándole a la prensa de la época la doble función de contribuir con el proceso de construcción de una ciudadanía y de crear un foro en el que la opinión pública encontrara a su 
genuino representante. En una sociedad donde el sufragio era falseado sistemáticamente, la prensa, para Duncan, habría sido el símbolo del compromiso con la república democrática, razón por la cual generalmente se la habría dejado actuar en libertad.

Su análisis sobre este tópico presenta severas debilidades frente a dos cuestiones principales. La primera se refiere a las características y vigencia de la libertad de expresión que será estudiada en el próximo ítem. De todos modos, puede adelantarse aquí que los argumentos ofrecidos a favor de su vigencia plena-verbigracia, que podían publicarse libremente libelos (aunque, como veremos, no siempre fue asî), y la reproducción de un documento oficial (en realidad, no sería muy razonable esperar que un original emanado de una oficina republicana saliera abiertamente a reconocer lo contrario)- son ciertamente muy débiles. La segunda, en tanto, alude la relación establecida entre la opinión pública, la prensa periódica y la sociedad civil, y podría presentarse del siguiente modo: ¿resulta apropiado considerar a la prensa de la época como una expresión de la sociedad civil?, y ¿la interpelación permanente a la opinión pública que formulaba la prensa política aludía a algún actor social preciso, o, por el contrario, se trataba de un concepto más político que sociológico que hacía referencia a un principio abstracto, ideológico, de legitimación, cuya representación todos los miembros del universo político se disputaban?

Respecto del primer interrogante, Paula Alonso ha demostrado que la evolución de la prensa política en la segunda mitad del siglo XIX no acompañó los cambios experimentados por la ciudad de
Buenos Aires como consecuencia de las políticas de alfabetización y el crecimiento económico. Si bien proliferaron nuevas publicaciones y aumentó la circulación de la prensa en general, la prensa política mantuvo su número y su tiraje, y continuó interpelando primordialmente a simpatizantes y adversarios. De este modo, su existencia no parece haber sido afectada por la sociología de la ciudad, ya que su relevancia no provenía de ser la promotora y representante de una opinión pública resultante de los cambios sociales, sino la expresión de círculos y facciones políti$\cos ^{37}$ Más aún, señala Alonso, sería ilusorio pensar en la opinión pública como una entidad que habría emergido espontáneamente de la sociedad rioplatense arrasada por las guerras civiles de la primera mitad del siglo para dirigir los asuntos del Estado y que se habría expresado principalmente a través de la prensa. Esta afirmación no implica desconocer que, eventualmente, ciertos grupos o comunidades se hicieron oir a través de la prensa, ${ }^{38}$ algunas asociaciones socioculturales pretendieron ejercer una especie de mediación entre la sociedad civil y el Estado destinada a representar la opinión pública y controlar el poder, ${ }^{39}$ y hasta, en algunos casos, los periódicos lanzaron con insistencia iniciativas que el gobierno se vio obligado a poner en práctica. ${ }^{40} \mathrm{Sin}$ embargo, no parece haberse tratado más que de excepciones puntuales que permiten confirmar la regla, antes que invalidarla.

37 Alonso, "Primavera", 1997, p. 45.

${ }^{38}$ Sabato y Cibotti, "Hacer", 1990.

${ }^{39}$ González, Civilidad, 2002, p. 168.

40 Véanse Sabato, Política, 1998, 3a. parte; Alonso, Revolución, 2000, cap. IV, y Lettieri, República, 2000 , cap. 5. 
Respecto del segundo interrogante planteado, se ha demostrado que la opinión pública constituyó, durante el periodo que me ocupa, un concepto más político que sociológico, que permitía designar a un principio abstracto de legitimación al que todas las fuerzas políticas interpelan para atribuirse una legitimidad indispensable. ${ }^{41}$ Una conclusión similar la arriban P. Alonso, E. Palti y N. Goldman en recientes estudios sobre el tema. ${ }^{42}$ De este modo, es posible afirmar que en Río de la Plata, a lo largo del siglo XIX, el concepto opinión pública remitió a una construcción ideológica, el "tribunal público", disputada por los participantes del juego político, quienes sistemáticamente se atribuyeron su representación. Tampoco quedan dudas respecto de que la prensa política fue uno de los principales escenarios de la disputa discursiva por la apropiación de la legitimidad -y, sin dudas, el más resonante y popular. Por ese motivo, justamente, la prensa no reflejó las características sociológicas de sus lectores, sino las estrategias que las dirigencias partidarias consideraron más adecuadas para interpelar y movilizar a quienes, de algún modo, se encontraban involucrados con el mundo de la política en el contexto de una competencia permanente por la legitimidad. ${ }^{43}$ Es decir: se trataba de una prensa política que expresaba las opiniones de quienes ejercían

41. Lettieri, Formación, 1995, "Construcción", 1995; "Formación", 1994, y Alonso, "Primavera", 1997 , p. 49.

${ }^{42}$ Alonso, "Primavera", 1997, p. 46; Palti, "Historia", 1999; Goldman, "Libertad", 2000.

${ }^{43}$ Este empleo del concepto opinión pública, y la función correspondiente dentro del sistema de legitimación, no constituye una característica específi- -o pretendían ejercer- el poder político, y no de una prensa "moderna", de información y negocios, encargada de expresar los juicios de una sociedad civil, cuyo tramado, ciertamente, no era suficientemente sólido como para someter el ejercicio del poder político a un control permanente.

Esta pretensión de legitimidad expresada por círculos y facciones se traducía, diariamente, en una decodificación del proceso histórico y de la actualidad política que formulaba la prensa política, con el objetivo de satisfacer los intereses y expectativas de los grupos que la editaban. En cada edición, los periódicos ofrecían un reticulado a través del cual sus fieles seguidores -involucrados de algún modo en los vaivenes de la política- podían interpretar las posiciones de los círculos o de las facciones sobre los grandes problemas provinciales o nacionales, así como de la disputa política cotidiana. Halperin Donghi ha estudiado en detalle uno de estos casos de construcción de un pasado expectable -probablemente el más logradopara reclamar la legitimidad de un liderazgo político: la historia de la provincia de Buenos Aires elaborada por Mitre en sus artículos de Los Debates, publicados durante el año 1857. Halperin señala que, en sucesivas intervenciones periodísticas, Mitre analizaba el proceso político provincial a partir de la Revolución de Mayo, utilizando una periodización que incluía tres épocas -la revolucionaria, la rivadaviana y la resistencia contra la tiranía rosista. La construcción se cerraba con una

ca del caso bonaerense, ya que registra numerosos antecedentes en la época. Al respecto, véanse Gunn, Beyond, 1968; Ozouf, "Lopinion", 1987, y Letrieri, Seis, 2004, cap. 5. 
conclusión taxativa: a lo largo de su historia, el pueblo porteño había estado comprometido permanentemente con la libertad, manifestándose dispuesto a dejar la última gota de su sangre en la lucha contra la tiranía. Frente a esta lectura autocelebratoria del pasado provincial, de nada sirvieron los ajustados comentarios de Calvo, quien puso en duda la posibilidad de que Rosas hubiera podido llegar al poder -y mantenerlo por más de 20 añosen caso de haber tenido que enfrentar la oposición unánime y decidida de sus comprovincianos. Ciertamente, a través de sus editoriales, Mitre había diseñado los trazos esenciales de una fable convenue que una opinión pública poco dispuesta a ser vinculada con el pasado rosista deseaba ansiosamente tener por válida. Pero, asimismo, esta elaboración perseguía la obtención de un efecto mucho más poderoso, al asociar esas tradiciones y ese espíritu porteño con el Partido de la Libertad -presentándolo como su decantación natural-, y reclamar para éste una legitimidad que no podía exhibir ninguna otra fuerza que, en el pasado, hubiera estado asociada al rosismo. ${ }^{44}$

Junto con estas grandes construcciones del pasado y de los grandes problemas provinciales o nacionales, las páginas de la prensa cobijaban también rumores, descalificaciones y ridiculizaciones del adversario y recreaciones interesadas de situaciones. A juicio de Alonso, era precisamente esta relación con la cotidianidad la que permitía republicanizar la política, convirtiéndola efectivamente en una res publica. En efecto, valiéndose de sus crónicas interesadas y de sus satirizaciones, la prensa arrebataba la política de

${ }^{44}$ Halperin, José, 1987, pp. 150-151. la intimidad del salón, de los banquetes e, incluso, de la correspondencia privada, para lanzarla al conocimiento público. La difusión de estos acontecimientos constituyó un efectivo recurso para integrar al público a la política, convirtiéndolo -más allá de su importancia cuantitativa- en un elemento de disputa entre los actores políticos. Esta lucha por el favor público impuso ciertas reglas de juego a las intervenciones de los políticos, exigiéndoles adoptar, por ejemplo, un lenguaje principista, o bien, asumir resueltamente la defensa del interés general. La búsqueda de la aprobación pública, asimismo, marcó a fuego el estilo político de la época, ya que condujo a muchos actores a adoptar posturas aguerridas y sarcásticas, utilizando con generosidad giros y recursos demagógicos que dificultaban la mantención de una aconsejable moderación, y cuyas consecuencias se hacían notar cuando los vaivenes del juego político exigían reformular el sistema de alianzas o la estrategia adoptada. ${ }^{45}$ Duncan afirma que esta vinculación entre prensa y política demuestra que esta última era un asunto mucho más público de lo que los estudios canónicos estuvieron dispuestos a aceptar. ${ }^{46}$ De este modo, si bien la sociedad civil no parece haber estado en condiciones de ejercer un control efectivo y permanente sobre el poder político -sobre todo en las primeras décadas posteriores a $\mathrm{Ca}-$ seros-, la pretensión de presentarse como legítimos representantes del interés general exigió que los actores políticos adoptaran decisiones y comportamientos susceptibles de ser sometidos al juicio de un abstracto "tribunal de la opinión".

\footnotetext{
45 Alonso, "Primavera", 1997, pp. 48-49.

${ }^{46}$ Duncan, "Prensa", 1980, p. 775.
} 
LA LIBERTAD DE IMPRENTA DE CASEROS A PAVÓN (1852-1861)

La cuestión de la libertad de imprenta en Río de la Plata en la segunda mitad del siglo XIX ha sido objeto de un largo debate en nuestra historiografía. La posición canónica se basa en el juicio de Sarmiento, quien aseguraba la vigencia de una plena libertad de prensa en Buenos Aires después de Caseros. Para Levene, por ejemplo, el "triunfo de Caseros significó, entre otras cosas, quitar la mordaza que trababa la dignidad periodística" ${ }^{47}$ Cárcano, por su parte, posterga el inicio de ese proceso al "11 de septiembre, [que] creó el poder de la crítica, con fuerza para hacerse escuchar y entender" ${ }^{48}$ Galván Moreno ha señalado que, tras el triunfo de los vencedores en Caseros, hubo un florecimiento de la prensa "como el vigoroso retoñar de los campos tras la lluvia benefactora después de una larga sequía" ${ }^{49}$ Entre los estudios más recientes, Duncan arriba a una conclusión similar para la década de los ochenta sin ofrecer elementos de juicio definitivos, y Cibotti apunta que todos los cronistas de la época destacan la "extraordinaria libertad de la que gozaba la prensa". 50

Sin embargo, estas argumentaciones no se destacan por su solidez, y a menudo

${ }^{47}$ Levene, Historia, 1940, t. 3, p. 377.

${ }^{48}$ Cárcano, Caseros, 1918, p. 212. El 11 de septiembre de 1852 , un levantamiento tramado por la dirigencia liberal, con el respaldo de la dirigencia urbana rosista y el financiamiento de las clases propietarias, puso fin al dominio de Urquiza sobre Buenos Aires. Véase Lettieri, Repriblica, 1999.

${ }^{49}$ Galván, Periodismo, 1944, p. 193.

${ }^{50}$ Duncan, "Prensa", 1.980, p. 778; Cibotti, "Mosquito", 1993, p. 12. relativizan sus taxativas afirmaciones iniciales. Por ejemplo, tras argumentar a favor de la existencia de una absoluta libertad de imprenta después de la caída de Rosas, Levene debe aceptar que, durante el tutelaje de Urquiza, la prensa porteña se vio obligada a utilizar un discurso sumamente cuidadoso, computando como errores u omisiones a las frecuentes actitudes autoritarias del Libertador, a fin de preservar una continuidad que no estaba en modo alguno garantizada. Galván Moreno acaba por reconocer que "aquel renacer floreciente de la pluma, el año 1852, era el fruto, más que del desahogo de la libertad, de las pasiones e intereses encontrados", por lo que resultó indispensable aplicar inmediatamente sanciones. ${ }^{51}$ Por su parte, Cibotti afirma que en los años ochenta se "impulsó infructuosamente un proyecto de reglamentación del ejercicio periodístico"; sin embargo, aunque fracasó la iniciativa, “'El Mosquito' debió pagar una fuerte multa". ${ }^{52}$ Otros autores, en cambio, han cuestionado con firmeza esta tesis. Adolfo Saldías ha puesto en cuestión la posición canónica, ${ }^{53}$ y Guillermo Furlong señala que estas

curiosas manifestaciones ni responden a la tradición argentina ni concuerdan con la yue podríamos llamar "doctrina nacional", desde Juan B. Alberdi hasta Jorge Mayer, ya que lógicamente la consideran como una libertad condicionada; una que no fuera tal, podría llegar a ser una amenaza a las institu-

${ }^{51}$ Galván, Periodismo, 1944, p. 196. Abad de Santillán sostiene una posición similar en Abad, Historia, 1965, vol. I, pp. 76-77.

${ }^{52}$ Cibotti, "Mosquito", 1993, p. 10.

${ }^{53}$ Saldías, Siglo, 1987, pp. 276 y ss. 
ciones fundamentales del país y llegar a provocar nuevas guerras civiles. ${ }^{54}$

La Constitución de 1853 otorgó abundantes garantías para la libertad de imprenta, y lo mismo hizo la Constitución provincial bonaerense de 1854. Sin embargo, ¿es posible sostener la vigencia de una amplísima libertad de prensa en Buenos Aires después de la caída de Rosas? Evidentemente, si por libertad de imprenta entendemos un grado mayor de autonomía de los editores y redactores de periódicos respecto de la autoridad estatal, los estudios de Néstor Auza ${ }^{55}$ y Tulio Halperin Dongui ${ }^{56}$ permiten afirmar, por ejemplo, que, en este aspecto, la prensa porteña habría gozado de una situación más beneficiosa que la que se desarrollaba en territorio de la Confederación, donde la actividad periodística era encomendada a empleados a sueldo de los Estados provinciales o nacional, o bien se encomendaba a inestables licenciatarios, sujetos a férreo control político.

Según se ha señalado, las elites dirigentes de la república de la opinión asignaban un papel esencial a la producción de un consenso significativo en la opinión pública, razón por la cual insistieron en retener un protagonismo decisivo en sus procesos de formación. Más aún, los actores más destacados de esa dirigencia se desempeñaron simultáneamente como re-

${ }^{54}$ Furlong agrega que este fue el pensar de Juan Bautista Alberdi, Facundo de Zuviría, Carlos Tejedor, Nicolás Avellaneda, Florentino González, Luis V. Varela, Aristóbulo del Valle, José Manuel Estrada y José María Moreno. Furlong, "Periodismo", 1966, vol. II, p. 225.

\footnotetext{
${ }_{55}$ Auza, Periodismo, 1978, p. 225.

${ }^{56}$ Halperin, José, 1987, p. 287.
}

dactores de la prensa política de la época, una prensa que no fue un emergente de la sociedad civil, sino uno de canales prioritarios a través de los cuales los círculos y facciones intentaban construir y renovar cotidianamente su legitimidad política. De este modo, la prensa constituyó un escenario primordial de la disjuta facciosa, en el que la continuidad de los emprendimientos dependió estrechamente de los subsidios y beneficios otorgados por el Estado.

Por ese motivo, cobra importancia estudiar con profundidad las características que adquirió la libertad de imprenta en los años cincuenta. Según se ha consignado, los estudios disponibles se han limitado generalmente a formular juicios de valor sobre esta cuestión, tanto en sentido afirmativo como negativo, cayendo en frecuentes contradicciones. Prima face, la dinámica política que adoptó la lucha facciosa en los años cincuenta no parece haber constituido un terreno propicio para la plena vigencia de la libertad de expresión. Sin embargo, tampoco parece adecuado formular la tesis inversa, en tanto la libertad de imprenta constituía un elemento central del nuevo universo ideológico que las elites liberales estaban decididas a imponer, y que habitualmente aparecía rodeado de elogiosos calificativos en el discurso público. Por esa razón, creo que resulta mucho más apropiado sostener, en una primera aproximación, que las posiciones de la nueva dirigencia política respecto de la libertad de imprenta habrían estado orientadas a delinear esa "posición intermedia" entre la independencia total y la subordinación, considerada deseable -aunque imposible de alcanzar - por Alexis de Tocqueville. Sin embargo, como bien advertía el autor 
francés, esta pretensión incluía en sí misma una tensión, cuyo equilibrio no podría sostenerse por demasiado tiempo.

Mi hipótesis en este caso es que, en los años cincuenta, las condiciones de posibilidad para la vigencia de la libertad de expresión y, sobre todo, los límites para la tolerancia del ejercicio del disenso, habrían estado estrechamente subordinadas a las reglas de juego impuestas por la evolución del equilibrio faccioso. Si bien la continuidad de los emprendimientos periodísticos estuvo ligada a las lealtades personales que podían capitalizar editores y redactores, la posibilidad de acceso a algún tipo de subsidio público y la inserción alcanzada en la opinión pública, estas variables dependieron en última instancia de la agitada dinámica política de la república de la opinión.

\section{La prensa de Buenos Aires: entre Caseros y la Revolución de Septiembre de 1852}

Tras la caída del régimen rosista en Buenos Aires, la subordinación de la actividad periodística a la lógica del juego faccioso constituyó una de las prioridades a resolver por las nuevas autoridades. En tal sentido, debe señalarse que, aun cuando una de las primeras medidas adoptadas después de Caseros por la administración de Vicente López y Planes fue la derogación de la ley de imprenta sancionada por el gobierno de Rosas, la norma que la reemplazó, sancionada el 18 de mayo de 1828 -y denominada popularmente "ley mordaza"-, proveyó de una herramienta maestra para recortar el ejercicio de la crítica, al prever la fijación de pesadas multas para los infractores, la clausura de medios opo- sitores y la alternativa de la cárcel y el destierro de sus editores. ${ }^{57}$

La adopción de la Ley de Prensa de 1828 permitía, en un solo acto, sustanciar un gesto político poderoso -la anulación de una legislación opresiva del rosismo-, sin que las instituciones provinciales vieran debilitado sustancialmente su control sobre las publicaciones. De este modo, quedaban fijados severos límites para el ejercicio de la libertad de imprenta. Por entonces, el convencimiento respecto de la necesidad de mantener a la prensa ceñida en un estrecho corsé no se limitaba a una facción política determinada, sino que permitía aglutinar prácticamente al conjunto del universo político de la época, con la única exclusión de aquellos actores o grupos que, puntualmente, se veían perjudicados por la aplicación de tan estricto control. Obsérvense, en tal sentido, algunos de los conceptos vertidos en la profesión de fe escrita por Mitre para el número inicial de Los Debates. En la ocasión, el periódico celebraba el restablecimiento de la libertad de imprenta, sin omitir destacar la gloria que correspondía al general Urquiza al impulsar la adopción de esta medida (recuérdese que el periódico habría de ser clausurado por disposición de Urquiza dos meses después): "Por la libertad de imprenta, el pueblo tiene entre sus manos el cerebro de la nación. Qué gloria para el general Urquiza haber restituido a su patria estas tres instituciones democráticas [la libre elección, la guardia nacional y la libertad de imprenta]." 58

57 Véase el texto de la ley en Myers, Orden, 1995 , pp. 1.31-132.

${ }^{58}$ Los Debates, 1 de abril de 1852. 
En realidad, la subordinación de la prensa a las reglas del juego político parece haber sido una preocupación constante a lo largo del siglo XIX, la cual se tradujo en la sanción de numerosas leyes y disposiciones. ${ }^{59}$ Durante el periodo que me ocupa, uno de los argumentos más consistentes en favor del sometimiento de la actividad de la prensa a los imperativos del proyecto político predominante fue expresado por Alberdi a fines de 1852. La cuestión a dirimir consistía, simplemente, en "saber qué pedía antes la política a la prensa, y que le pide hoy desde la caída de Rosas".

Una ley de 26 de octubre de 1810 proclamó el principio de la libertad de prensa; pero fue entendido que ese principio no sería em-

s9 "A la libertad de prensa y a sus legítimos límites [apunta Furlong] se refieren múltiples documentos, entre 1810 y 1852 , tales como los decretos del 20 de abril y del 26 de octubre de 1811 , los proyectos de Constitución de 1813, los estatutos de 1815 , 1816 y 1817, los proyectos de Constitución de 1818 y 1819 , el decreto del general San Martín, de 13 de octubre de 1822 y 8 de mayo de 1828 , los decretos del 30 de octubre y 31 de diciembre de 1829 , y el acuerdo del 3 de febrero de 1831 , el decreto del 1 de febrero de 1832 , las leyes del 22 de junio de 1833 , 15 de octubre y 9 de noviembre de 1833 y 3 de septiembre de 1834. Después de Caseros los abusos de la libertad de prensa fueron tales que Buenos Aires expide los decretos del 28 de febrero y del 1 de julio de 1852 y, no obstante lo consignado en la Constitución provincial del 1 de abril de 1854 , se aprueba la ley del 17 de septiembre de 1857 , a la que siguen los decretos del 7 de abril de 1859 y 18 de febrero de 1861, y la Constitución de 1873. Años antes, en 1867, Avellaneda había presentado un proyecto para encauzar la conveniente libertad de prensa y, en 1875, Luis V. Varela presentó otro proyecto con igual objetivo." Furlong, "Periodismo", 1966, p. 220.

${ }^{60}$ Alberdi, Cartas, 1932, p. 13. pleado contra la Revolución de Mayo y en defensa de los opositores españoles a la nueva autoridad patria. El abuso de la libertad fue declarado crimen; y se declaró abusivo todo escrito que comprometiese la tranquilidad o la constitución del Estado. En una palabra, la prensa sólo fue libre para defender la Revolución de Mayo. He ahí la única prensa que hará posible la creación de la autoridad en la situación presente de la república Argentina: la prensa que tiene poder para ilustrar a la sociedad, pero no para destruirla y ensangrentarla. ${ }^{61}$

Como objetivo manifiesto, los argumentos de Alberdi apuntaban a la creación y consolidación de la autoridad nacional en Argentina, preservándola de los ataques de los "montoneros de la prensa", expresión con la que definía a Mitre, a Sarmiento y a sus socios septembrinos. Sin embargo, su filosofía profunda revelaba una matriz oficialista y conservadora, que tanto podría ser esgrimida por Urqui$\mathrm{za}$, cuanto por cualquier otro poder celoso de construir y conservar su autoridad. Efectivamente, nada impedía que la Revolución de Sepriembre -como había sucedido en su momento con la Revolución de Mayo- considerara legítimo subordinar la libertad de prensa -o, mejor dicho, impedir el "abuso" de la libertad de prensa- a su proyecto político, para evitar que los opositores utilizaran este medio para "comprometer la tranquilidad o la constitución del Estado". De este modo, no escapaba al sentido común de la época que los revolucionarios de Buenos Aires concibiesen que la prensa sólo debía ser libre para defender a la Revolución de

${ }^{61}$ Alberdi, Derecho, 1918, pp. 351-353. 


\section{SECUENCIA}

\section{AGRA AND ENVIRONS}
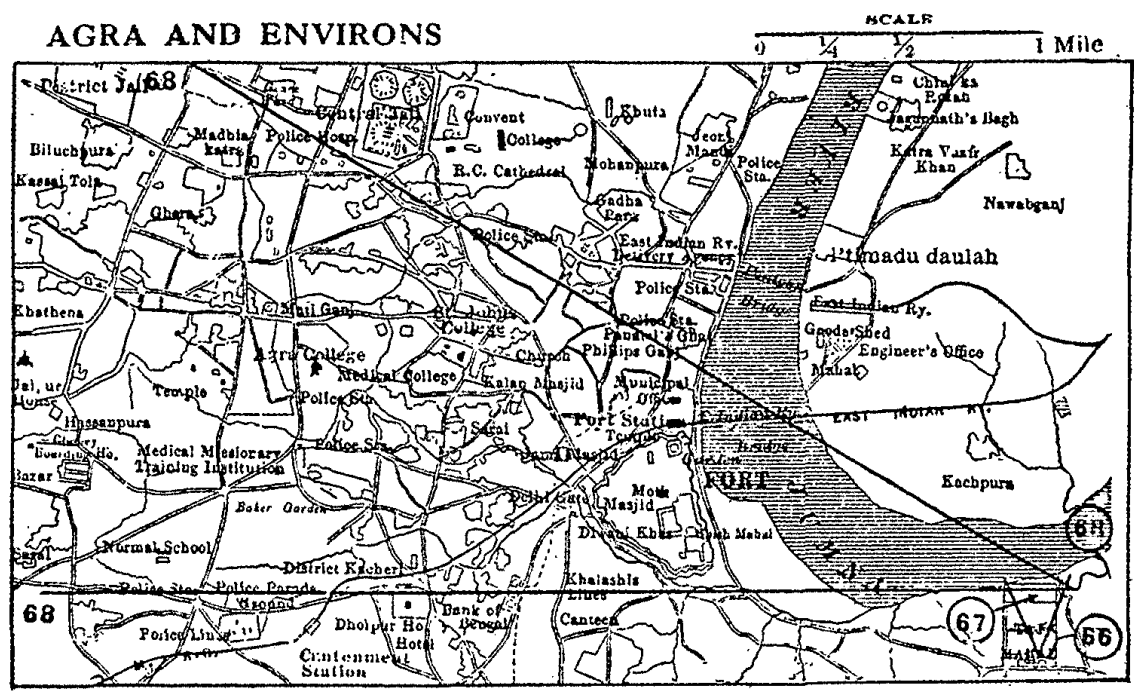
Septiembre, y se adjudicasen a sí mismos las tareas de ilustrar a la sociedad y de promover su progreso material y moral.

Los argumentos del tucumano hacían un flaco favor a la causa de la libertad de expresión. En realidad, su interés estaba puesto en diseñar una herramienta que juzgaba esencial para el proceso de construcción de la autoridad política, antes que en favorecer el ejercicio de una oposición considerada dilatoria. Para Alberdi, era deseable obtener la subordinación de la prensa estimulando la autocensura de editores y redactores, provocada por la amenaza cierta de sanciones pecuniarias o físicas, antes que a través del ejercicio de la censura desnuda. La atracción de esta prescripción era tal que no sólo conseguiría subyugar al poder nacional, sino también a los fautores de la naciente república de la opinión en Buenos Aires. Para hacer justicia con Alberdi, es necesario hacer notar que si bien estas tesis restrictivas fueron expresadas con claridad prístina por el tucumano, éste no ofició como predicador de un mensaje que no fuera compartido por el resto; por el contrario, tales argumentos ya habían aflorado en Buenos Aires algunos meses atrás, de manera un tanto desagregada, cuando la Sala de Representantes puso en discusión un pedido del gobernador López y Planes para reprimir la violenta crítica desplegada por la prensa opositora.

Al respecto, señala Ramón J. Cárcano que:

El pueblo de Buenos Aires se conmovió a la propaganda. El gobierno necesitó solicitar de la legislatura medidas de represión a la licencia de la prensa; Mitre y Estévez Saguí presentaron proyectos para cortar sus excesos sin trabar la libertad; la policía clausuró por fin el primer diario por el desenfreno de sus pasiones. ${ }^{62}$

El argumento no sólo traduce la concepción de Cárcano -compartida por otros autores, como Abad de Santillán, Galván Moreno o Furlong- sobre las características tolerables para el ejercicio de la libertad de expresión, sino que también nos ofrece un somero cuadro introductorio sobre la situación de esta libertad después de Caseros. La solicitud de López y Planes resulta doblemente significativa, no sólo porque culminó con la clausura de los primeros periódicos tras la caída del régimen rosista, sino porque significó el punto de partida para un debate en el que los interesados fueron definiendo y reorganizando sus argumentos a medida que el tablero político se modificaba. A continuación, me detendré a desarrollar esta última cuestión.

La libertad de prensa y las Jornadas de Junio de 1852

En el mes de mayo de 1852, el gobernador López y Planes solicitó que la Sala de Representantes sancionara a los periódicos La Nueva Época, El Padre Castañeta,

${ }^{62}$ Cárcano, "Reorganización", 1947. Las actas de la Sala de Representantes dan cuenta de este pedido: "Se dio cuenta en seguida de dos notas del excelentísimo gobierno provisorio; en la otra se proponía a la aprobación de la Sala un acuerdo del poder ejecutivo dictando providencias para contener los abusos actuales de la prensa periódica, y se remitió a la Comisión de Legislación. Se dio cuenta de dos mociones del señor diputado Estévez Saguí sobre cortar el abuso que se hace de la libertad de prensa: ambas fueron apoyadas debidamente." Sala, Diario, 12 de mayo de 1852, p. 20. 
La Avispa y El Torito, y encomendase al fiscal la acusación de los redactores respectivos, argumentando la comisión de abusos. Poco después, sin esperar la decisión de la Sala de Representantes, López y Planes firmó un decreto fechado el 12 de mayo que disponía la clausura de aquellos periódicos, considerándolos frutos de las "malas pasiones y de la perversidad, receptáculo de calumnias anónimas y que, lejos de contribuir a la ilustración del pueblo, lo desmoralizan".63

Los redactores de Los Debates, entre los que se contaban Bartolomé Mitre, Manuel Montes de Oca, Luis Domínguez y Juan Carlos Gómez, quienes según se ha consignado pocos días atrás habían celebrado el inicio de la vigencia de la libertad de prensa, no objetaron la decisión de López y Planes. Más aún, señala Furlong, aplaudieron la energía de la medida. Acompañando la decisión de López y Planes, poco después los legisladores Saguí y Mitre presentaron sendas iniciativas. El 17 de mayo de 1852 Bartolomé Mitre propuso un minucioso proyecto sobre "uso y abuso de la imprenta":

[Se da cuenta de] un proyecto de ley presentado por el señor Mitre sobre el uso y abuso de la imprenta en 95 artículos, y habiendo sido apoyado después de leído, lo fundó su autor, exponiendo que aunque su opinión era que el mejor remedio del abuso de imprenta es dejarla en absoluta libertad, sin embargo, en el lugar que ocupa de diputado es legislador y no filósofo, por lo que había trabajado este proyecto, sobre el que se extendería a su tiempo. ${ }^{64}$

6315 de mayo de 1852 en Sala, Diario, 18521854 , p. 20.

${ }^{64} 17$ de mayo de 1852 en ibid, p. 40.
Por su parte, Estévez Saguí proponía respaldar la decisión del gobernador con una sanción legislativa, ya que la resolución de cuestiones vinculadas con el delito de abuso de la libertad de prensa era una competencia natural de la Sala.

Estoy muy distante de coartar las libertades públicas, por las que estoy decidido a derramar mi sangre si necesario fuese; pero es de mi deber el promover que el país aparezca en su dignidad, y no en el estado vergonzoso en que lo colocan algunos hombres, que quizá con objetos siniestros tratan de explotar las circunstancias actuales; y me felicito de haber prevenido al gobierno en la materia; pues era a la Sala que correspondía tratar del remedio a tanto mal, sin esperar a que se invocase por otra autoridad. ${ }^{65}$

Al señalar que su función como diputado era la de "legislador y no [la de] fílósofo", Mitre expresaba con claridad que, pese a su inclinación por la vigencia de una amplia libertad de imprenta, debía aceptar que ésta no era posible en las circunstancias que lo rodeaban. Inmediatament reconocía que se trataba de una cuestión decididamente política, lectura que era corroborada por la minuciosidad del proyecto de ley que adjuntaba, el que contaba, nada menos, que de 95 artículos. Según señala Lucian Pye, ${ }^{66}$ en ningún lugar del mundo, en época alguna, una legislación generosa sobre libertad de imprenta necesitó ser expresada en una cantidad numerosa de ítems. El representante Estévez Saguí, por su parte, tras ex-

${ }^{65}$ Ibid, p. 43.

${ }^{60}$ Véase Pye, Evolución, 1969. En especial el capítulo rv, escrito por Shils, "Demagogos", 1969, y Álvarez y Martínez, Historia, 1992. 
presar su compromiso con las libertades públicas, no sólo justificaba la represión de periódicos sospechosos de complicidad con algún tipo de restauración del régimen rosista, sino que se felicitaba de "haber prevenido al gobierno en la materia".

Los testimonios son reveladores. Efectivamente, la cuestión de la libertad de imprenta en Buenos Aires -y en el territorio nacional en general- a lo largo de los años cincuenta adquirió una matriz decididamente política. Por este motivo, los argumentos de los actores distaron de responder a principios y criterios generales y universalmente válidos, y se fueron redefiniendo a medida que se modificaba su situación en el universo político provincial o nacional. Esta afirmación puede ser comprobada con sólo repasar el desarrollo de este debate.

Animado por los testimonios de los representantes, el gobierno provincial decidió clausurar por su cuenta, por el plazo de diez días, los periódicos acusados, omitiendo disponer la formación de un tribunal especial para tratar la cuestión, como era de práctica en la provincia. Sin embargo, poco después, el 1 de junio de 1852, la Sala de Representantes, que inicialmente había ofrecido signos de aprobación de la medida, procedió a analizarla minuciosamente. ¿A qué se debía este cambio? Nada menos que a la modificación significativa que había experimentado la situación política en el ínterin: ahora buena parte de la dirigencia liberal se encontraba enfrascada en la crítica a la decisión inconsulta del gobernador provincial de concurrir a la reunión de San Nicolás.

Por entonces, la prensa se constituyó en una de las principales tribunas utilizadas por el liberalismo radical para difundir su voz sobre la naciente opinión pública porteña. ${ }^{67}$ Por ese motivo, la cuestión de la legitimidad del ejercicio de la censura y de la represión sobre la actividad de la prensa cobraba en este momento un nuevo matiz, en tanto pasaba a afectar directamente la acción de este grupo político. De este modo, no puede sorprender demasiado que la dirigencia liberal se evidenciara decidida a examinar la política de prensa del gobierno de López y Planes ni, mucho menos, el profundo giro que experimentaron los argumentos vertidos por la Comisión y por algunos caracterizados representantes durante el debate. La minuta elaborada por ésta y presentada en la sesión del 1 de junio era clara y precisa. ${ }^{68} \mathrm{Si}$ bien, en su momento, los representantes provinciales habían aceptado que la cuestión de la libertad de prensa era fundamentalmente política, y hasta se había encomiado la enérgica actitud del gobierno para remediar rápidamente el "abuso" en que habrian incurrido algunos medios, respaldando inicialmente la aplicación de sanciones. Ahora -en el marco del proceso que decantará en las Jornadas de Junio- un sector significativo de los legisladores liberales expresará su desacuerdo con la aplicación de castigos sobre la prensa, denunciando la violencia que esto significaba y manifestando su esperanza de que tales hechos no se repitiesen, para que la libertad que nacía de la ley que los representantes han jurado sostener no se viera comprometida. La magnitud del cambio en las posiciones es radical, aunque no resulta incoherente con la dinámica política que he tratado de reconstruir en los capítulos precedentes.

${ }^{67}$ Lettieri, República, 1999.

${ }_{68} 1$ de junio de 1852 en Sala, Diurio, $1852-$ 1854, p. 62. 
De todos modos, ésta no era una posición unánime dentro de la Sala, tal como permite comprobarlo el debate que sucedió a la presentación de esta minuta. Ante la solicitud formulada por algunos representantes de agregar al texto referido una condena más explicita, o bien una nota de repudio a la actitud del gobierno provincial, el vocero de la comisión, Portela, se apresuró a poner paños fríos a la cuestión, señalando que el gobierno no actuaba inspirado por el autoritarismo, sino obligado por las circunstancias "apremiantes y excepcionales" que atravesaba la provincia. La minuta de la comisión no sólo encontró resistencias de parte de quienes la consideraban excesivamente recatada, sino también de aquellos que juzgaban su tono agresivo, inapropiado e irrespetuoso, como fue el caso del rosista Martínez. Si bien no debe omitirse justipreciar las convicciones íntimas de los representantes sobre la cuestión de la libertad de imprenta en la elaboración de sus argumentos, el arco de posiciones que es posible reconstruir expresaba con bastante fidelidad las estrategias adoptadas por los diversos círculos provinciales respecto del gobierno porteño $\mathrm{y}$, fundamentalmente, del poder de quien constituía su principal respaldo político: el general Urquiza. Por ejemplo, desde el liberalismo, Dalmacio Vélez Sársfield -quien todavía no había roto las lanzas con el gobierno provincial y que aún guardaba expectativas ciertas sobre una solución consensuada para la reunión de San Nicolás- aconsejaba actuar con cautela y moderación:

Yo estoy en contra de su redacción (de la minuta) por parecer muy respetuosa y hasta cierto punto ofensiva al poder ejecutivo; a mi modo de ver, es arrojarle el guante y ponerlo en el caso de hacer su decisión, creyendo haber perdido la confianza del cuerpo legislativo. ${ }^{69}$

Finalmente, los representantes Saguí y Mitre, quienes habían apoyado respecitvamente con entusiasmo la iniciativa del gobierno y propuesto una minuciosa reglamentación sobre la libertad de imprenta, ahora descargaban enérgicas condenas. Según relata la crónica de la sesión:

El señor Estévez Saguí fundó con energía el derecho de la libre emisión de las ideas apoyando su razonamiento en el testimonio de rodos los países que gozan de más libertad y más solidamente constituidos, pues en ellos se respetaba la libertad absoluta de emitir los pensamientos. ${ }^{70}$

Bartolomé Mitre -quien para este momento ya había adelantado sus objeciones a la decisión del gobierno provincial de concurrir a la reunión de San Nicolás sin haber solicitado la autorización respectiva de la Sala de Representantes-, en tanto, retomaba aquí el mismo argumento del vicio de procedimiento para impugnar la decisión del ministerio público, el cual había impuesto una sanción por sí mismo, prescindiendo de disponer la formación de un tribunal específico:

Aunque temo ser colocado en el número de los insensatos, debo expresar con franqueza que no estoy por la medida del gobierno, $y$ aquí al expresarme así no es mi ánimo atacar al gobierno provisorio ni hacerme solidario con los periódicos que, ex cátedra, han sido declarados como abusivos de la libertad de

69. Ibid., p. 64.

${ }^{70}$ Ibid., p. 67. 
prensa. Creo también que el gobierno debió haber previsto la formación de un tribunal para juzgar los abusos de la libertad de imprenta.

Algunos días después, el propio Mitre formulaba una condena aún más terminante: "Aunque no soy doctor de la ley, he sido graduado por el pueblo para hacer sus leyes. Es indudable que la propiedad ha sido atacada habiéndose impuesto no sólo una pena a los periódicos, sino al medio de su colaboración." 71

El debate sobre la decisión gubernamental de sancionar a los periódicos que habrían incurrido en "excesos" en el ejercicio de la libertad de imprenta terminó con una solución de compromiso, ya que la Sala de Representantes decidió aprobar una minuta de tono moderado, en la que renovaba su compromiso con la libertad de imprenta, sin formular críticas al gobierno provincial. La solución pretendía encontrar un justo medio entre las posiciones encontradas de los representantes, sin conseguirlo, ya que la mayoría expresó su disconformidad. De todos modos, la cuestión de la libertad de imprenta y de los límites a su ejercicio no resignó su actualidad. En efecto, pocos días después la prensa sería el ámbito elegido por los políticos liberales para dar vida al nuevo discurso de la legitimidad, característico de la república de la opinión, que habrá de consagrarse de manera definitiva tras la victoria de la Revolución de Septiembre. ${ }^{72}$ En efecto, la prédica de la prensa liberal recibió una respuesta muy favorable de parte de una naciente opinión pública, que apoyó las denuncias y exi-

${ }^{71} 9$ de junio de 1852, en ibid., p. 96.

${ }^{72}$ Lettieri, Repríblica, 1999, caps. 2 y 3. gencias formuladas mediante la presentación de solicitadas y la asistencia masiva al recinto de la Sala al momento de discutirse los términos del Acuerdo de San Nicolás. Abrumado por los argumentos descargados por la oposición liberal, así como también por los signos manifiestos de desaprobación que le profesó el público que atestaba la Sala y las proximidades del recinto, el gobierno de López y Planes renunció en pleno una vez concluido el segundo día de discusión, luego de retirarse del teatro de las sesiones protegido por la fuerza pública.

Urquiza reaccionó inmediatamente frente a tales sucesos, disolvió la Sala y tepuso al gobierno renunciante, afirmando que su deber era "salvar la patria de la demagogia, después de haberla libertado de la tiranía" ${ }^{73}$ También clausuró a los periódicos que habían encabezado la oposición al Acuerdo de San Nicolás, y sus editores y redactores fueron deportados a Montevideo. Finalmente, el 25 de junio de 1852, López y Planes -ya repuesto en sus funciones de gobernador-impuso por decreto la censura previa, manifestándose dispuesto a liquidar la "licencia con que puede abusarse de la prensa, porque hay casos en que semejante abuso anarquiza y destruye el prestigio de la autoridad". ${ }^{74}$ Según Saldías, esta medida restrictiva de la libertad de imprenta fue, prácticamente, la única decisión de relevancia tomada por el anciano gobernador antes de dimitir en forma definitiva algunas semanas después. $^{75}$

${ }^{73}$ Citado en Levene, Historia, 1940, vol. I, p. 389.

${ }^{74}$ Furlong, "Periodismo", 1966, vol. II, p. 203.

${ }^{75}$ Saldías, Siglo, 1987, t. 11, p. 71. En sentido similar se expresa Levene, Historia, 1940, vol. I, p. 380 . 
Tras la asunción personal de la gobernación de Buenos Aires por parte del general Urquiza, en virtud de un artículo del Acuerdo objetado -y que no parecía tener validez legal, ya que la Sala de Representantes no lo había refrendado-, la situación de la prensa provincial sólo se modificó levemente, ya que la libertad de imprenta no experimentó mayores progresos. $^{76}$

\section{La prensa en la república de la opinión}

¿Era esta prensa encorsetada y subordinada al poder estatal, privada de la posibilidad de ejercer cualquier clase de crítica al gobierno, la que Alberdi imaginaba apropiada para abonar el proceso de organización política definitiva de la república? De las reflexiones de Alberdi sobre la prensa periódica en sus Cartas quillotanas puede extraerse, justamente, que el criterio utilizado para distinguir a los "montoneros de la prensa" de Buenos Aires de la prensa recomendada para lograr la modernización de la sociedad nativa, no parecía ser otro que el grado de adhesión que ese periodismo estaba dispuesto a profesar respecto del proyecto nacional expuesto en Las bases. De este modo, las intervenciones del tucumano sobre la prensa remitían más a definir las características de una

${ }^{76}$ Al respecto, apunta Levene: "Las imprentas que con motivo del golpe de Estado de Urquiza habían sido clausuradas, fueron reabiertas. Ias imprentas que editaban periódicos quedaban en libertad absoluta de publicar todo aquello que no significara crítica abierta al gobierno. Para aquellos asuntos en los cuales la crítica podía ser peligrosa se establecía un jurado formado por el general Manuel G. Pinto, don Marcos Sastre y don Fabián Molina." Ibid., p. 390. prensa instrumental para el proceso de transformación, antes que a garantizar las condiciones elementales de la libertad de prensa.

Sin embargo, sería inapropiado afirmar que esta posición haya sido una constante en Alberdi a lo largo de su vida. Poco después de la consolidación de la secesión porteña y la conformación de los dos Estados antagonistas sobre el suelo nacional -Buenos Aires y la Confederación-, evaluará las características de la prensa aplicando un prisma muy diferente al utilizado en 1852 :

No pretendo desconocer que hay contradicción y debate en esa prensa. Lo que niego es que esos debates sean pruebas de libertad. Hay dos opiniones en choque, porque hay dos gobiernos incompatibles. Cada opinión es libre para atacar al gobierno rival en defensa del gobierno propio, es decir, que ambas son oficiales. Nadie es libre para atacar a los dos gobiernos, en defensa de la nación explotada por ambos. ${ }^{77}$

Esta lectura sobre la prensa argentina correspondiente al año 1856 permite abonar la tesis de Shumway respecto de que Las bases constituye, probablemente, el trabajo más atípico de Alberdi, y más contradictorio respecto de su obra en general; sin embargo, en virtud del papel de "decálogo" que le otorgaron las clases dirigentes argentinas, habitualmente se lo identifica como una especie de compendio de su pensamiento. Esta cuestión ya ha sido tratada de maneta suficiente, por lo que no volveré a discutirla aquí. ${ }^{78}$ Sí, en cambio, me interesa señalar que, a

77 Alberdi, Obras, 1917 , t. vi, p. 394.

${ }^{78}$ Véase Lettieri, "República", 1999, p. 76. 
los efectos de la construcción de un poder de autoridad -proceso que combina elementos consensuales y coercitivos-, la tesis de Alberdi de 1852 parece haber adquirido un atractivo especial para las dirigencias -tanto provincial como nacionaldispuestas a beneficiarse con su aplicación, ya que adjudicaba a la propia elite decidida a monopolizar el poder político la competencia de legislar sobre los límites y condiciones de ejercicio de la libertad de expresión, sin que simultáneamente fueran previstos correctivos precisos para preservar de su poder e influencias a las voces que eventualmente quisieran expresar su disenso.

En tal sentido, los estudios disponibles permiten afirmar que, en Buenos Aires, los límites para el ejercicio de la libertad de prensa parecen haber sido un tanto más flexibles que en territorio de la Confederación. Pese a ello, las posibilidades de expresar el disenso parecen haber sido bastante limitadas, dependiendo en buena medida de las lealtades cosechadas por los editores, su vinculación con la "situación" y la evolución del equilibrio político.

La legislación sobre la prensa: juicios y redefiniciones

En la sesión de la Sala de Representantes del 3 de abril de 1854, el ministro de $\mathrm{Ha}-$ cienda de la provincia presentó un interesante argumento sobre la cuestión de la libertad de prensa. La reunión estaba destinada a tratar una solicitud de poderes extraordinarios formulada por la gobernación provincial, en razón de los fallidos intentos de invasión sufridos en los primeros meses del año. En la ocasión, el ministro denunció la propaganda desple- gada por Urquiza a través de la prensa, adjudicando a la ley de imprenta vigente una manifiesta debilidad para reprimir tales ataques. ${ }^{79}$ Estas declaraciones ministeriales no constituyeron un hecho aislado en la vida de la república de la opinión. Por el contrario, a lo largo de la década de 1850 la dirigencia insistió en sus críticas sobre la debilidad del instrumento legal disponible, la Ley de Imprenta, para reprimir los "abusos" en que habrían incurrido los periódicos opositores. Cabe aclarar que estos "abusos", que, desde una perspectiva actual difícilmente podrían ser calificados como tales -verbigracia, el aliento de la causa nacional, la reivindicación de la figura de Urquiza (muchas veces velada) o la publicación de libelos que desacreditaban a algunas de las principales figuras del régimen republicano-, eran considerados como una gravísima amenaza por parte de una dirigencia escasamente consolidada, que diariamente debía dedicarse a fundamentar su legitimidad ante un abstracto "tribunal de la opinión pública", y que no mostraba mayor predisposición para permitir la circulación de discursos políticos opositores.

Estos reclamos en favor de una modificación de la Ley de Imprenta vigente no consiguieron fecundar en una nueva legislación dotada de una mayor capacidad coercitiva hasta el año 1857. Sin embargo, es de hacer notar que, pese a esto, la alegada "insuficiencia" de la ley no impidió que, tanto en 1852 como en 1854, diversos periódicos opositores sufrieran clausuras, multas y el exilio o la detención de sus editores o redactores. ${ }^{80}$ En todos los casos, el

${ }^{79}$ Véase 3 de abril de 1854 en Sala, Diario, 1852-1854.

${ }^{80}$ Véase Abad, Historia, 1965, t. 3, pp. 55 y ss. 
gobierno o el Estado provincial justificaron las sentencias invocando actuar en beneficio del bienestar general. Sin embargo, la ruptura definitiva de la alianza colegiada entre liberales y rosistas, en 1857 , trajo aparejado un cambio significativo en la legislación de prensa. El 15 de septiembre de 1857, la Legislatura porteña se abocó a discutir un proyecto presentado por el nuevo gobernador, Valentín Alsina, y su ministro Domingo F. Sarmiento, que disponía someter los "delitos de prensa" a los tribunales ordinarios. ${ }^{81}$ Los argumentos para sostener esta propuesta fueron presentados en la sesión por el propio Sarmiento. En su intervención, reconocía la importancia de la crítica ejercida por la prensa como correctivo para evitar la tendencia de los poderes públicos de absorber más poder. Sin embargo, cargaba las tintas sobre la necesidad de prevenir el libelo -cuya tolerancia, se ha señalado, constituía para Duncan una prueba taxativa de la vigencia de la libertad de prensa-, reclamando que este tipo de delitos fuera sometido a los tribunales ordinarios, y considerados como un delito común. ${ }^{82}$

La iniciativa oficial fue contestada por el senador Portela, quien dividía su intervención en dos partes. En la primera, formulaba la valoración de la libertad de prensa característica del discurso político de la época, afirmando que la prensa libre constituía una precondición para la exis-

81 "Ias acciones de los particulares por injurias, calumnias o difamaciones que se cometan por la prensa, como también las que en su caso corresponde intentar a los fiscales del Estado, podrán ser deducidas ante los jueces ordinarios, los cuales lo juzgarán por las leyes civiles o criminales." Cámara de Senadores, Diario, pp. 346-349.

82 Ibid. tencia de la libertad política. Sin embargo, a continuación denunciaba que en la provincia se habían constatado numerosos "abusos" a esa libertad, y censuraba la iniciativa oficial, considerando que la misma era el resultado del apresuramiento, y que sus disposiciones implicaban un inaceptable retorno a la legislación de los tiempos coloniales. Después de descalificar el proyecto oficial, Portela pasaba a afirmar que no eran las injurias personales a las que aludía la ley los delitos que debían preocupar a la dirigencia -y a la sociedad en general-, sino aquellos que "afectan al orden público y tienden a viciar la opinión". En tal sentido, advierte que no lo satisfacen las soluciones que plantean que "los abusos de la prensa se corrigen por la prensa misma". Por último, Portela concluía aseverando que la aplicación de la ley propuesta, signada por sus resabios coloniales, no tendría ningún resultado positivo, $y$, para peor, podría dañar sensiblemente la vigencia de la libertad de prensa.

Una vez más, Portela volvía sobre la cuestión clave de los límites tolerables para el ejercicio del disenso dentro de la república porteña. La libertad de expresión era un bien invalorable, siempre y cuando ella no fuese utilizada para afectar el orden público y "viciar la opinión". Pese a que esta cuestión estaba presente en las intervenciones, los argumentos de los demás legisladores no consiguieron obtener mayor respaldo. En tal sentido, la intervención del senador Gamboa traducía esa preocupación común, expresada a través del curioso argumento al que apelaban para sostener la iniciativa oficial: la fijación de límites al ejercicio de la libertad de expresión era una benéfica iniciativa, que significaba una garantía para el ejercicio de la libertad de pensamiento: 
Es indudable, señor, que la libertad de prensa es hija de la justicia, es el órgano por donde se puede conocer la opinion pública, pero también es preciso que no degenere en licencia y que siempre que llegue a este límite, es preciso, de algún modo contenerla [...] Esto en nada toca a la libertad de pensamiento, al contrario, me parece que le da una mayor garantía. ${ }^{83}$

La iniciativa de la gobernación fue aprobada sin dilación por la Legislatura provincial, que vio en ella una herramienta adecuada para combatir los "excesos" de la prensa. Evidentemente, la retracción de algunos aspectos centrales de la legislación a la vigente en los tiempos coloniales no expresaba, precisamente, la voluntad de garantizar el ejercicio del disenso y de la libertad de expresión, sino, por el contrario, la decisión de imponerle muchos más precisos. Los resultados de su aplicación serían sumamente graves, y todavía en la década siguiente seguiría designándosele como la "ley bárbara del 57 ". 84 Sin embargo, la adopción de esta nueva legislación no dejó de generar dudas, incluso entre quienes posibilitaron su aprobación. Sus dudas no diferían de las expresadas por el senador Portela al momento de formular su impugnación a la iniciativa, ya que si bien se consideraba que la falta de una apropiada herramienta coercitiva para reprimir los "excesos" de la libertad de prensa podría ser aprovechada por los enemigos del régimen para "viciar" o "envenenar" a la opinión pública, la disposición de una robusta herramienta represiva podría tener

${ }^{83}$ Ibid.

${ }^{84}$ Lettieri, "Construcción", 1995, y Formación, 1995. un efecto inverso al buscado, al subordinar estrechamente a la prensa a las reglas del juego político, colocando entre interrogantes las posibilidades de vigencia de la libertad de prensa y, por extensión, de la propia libertad política.

\section{La libertad de imprenta a la luz de los cambios en el juego político}

Las posiciones adoptadas por el liberalismo provincial estuvieron estrechamente relacionadas con los cambios en la situación relativa de la dirigencia facciosa a lo largo de la década de 1850 . En tal sentido, ya se han apuntado las variaciones en las posiciones sustentadas durante el año 1852 , en relación con las modificaciones en los alineamientos políticos y la redefinición de la estrategia política que eso supuso. A continuación me interesa analizar las políticas y posiciones adoptadas en relación con la cuestión de la libertad de prensa en la segunda mitad de los años cincuenta. En primer lugar, analizaré las políticas delineadas por el liberalismo gobernante para limitar -o liquidar- el ejercicio del disenso por parte de los grupos antagónicos. Estudiaré las posiciones levantadas en relación con la cuestión de la libertad de expresión después de la batalla de Cepeda y los cambios en los argumentos sostenidos que supuso esa transformación del equilibrio político nacional.

\section{El liberalismo a la ofensiva: La Reforma Pacífica y La Prensa}

La Ley de Imprenta de 1857 fue sancionada en condiciones históricas precisas, que marcaban un punto de inflexión en la 
república de la opinión, ya que si bien, por una parte, confirmaron un final ya largamente anunciado del pacto entre liberales y federales, esta ruptura también significó simultáneamente la consagración de una alianza que venía gestándose desde hacía algún tiempo entre los federales bonaerenses y Urquiza. En cierta forma, este acuerdo había sido propiciado por la expresión política de liberalismo porteño -el Partido de la Libertad-, al recortar en forma implacable todos los intersticios que posibilitaban la participación institucional del rosismo. Así, perjudicados por el ejercicio del fraude electoral y afectados por la concentración de cargos públicos en manos de sus adversarios, los federales porteños no encontraron mejor alternativa que entregarse mansamente en brazos de Urquiza.

En realidad, los reclamos y argumentos vertidos por la dirigencia federal en los años anteriores al quiebre definitivo de la convivencia entre liberales y federales de $1857^{85}$ permiten postular que esta definición no había sido sino el producto de la voluntad manifiesta de los liberales de monopolizar la administración de la provincia. En términos de la relación entre periodismo y política, puede afirmarse que, mientras estuvo en vigencia el acuerdo entre federales y liberales que dio vida a la repuíblica de la opinión, la prensa se vio beneficiada, ya que predominaron las posiciones comunes de oposición a Urquiza. Al respecto, Abad de Santillán señala que la prensa porteña fue un "arma de lucha contra Urquiza y sus realizaciones". ${ }^{86}$ Pese a ello, en algunos casos la actividad periodística se vio constreñida por

${ }^{85}$ Lettieri, República, 1999, cap. 4.

${ }^{86}$ Abad, Historia, 1965, t. 3, p. 78. la acción gubernativa sobre la libertad de prensa. En 1852 Carlos Desins solicitó licencia para editar El Correo Argentino, asegurando que "no contendría ni una línea a favor del poder caído y sería muy favorable a la feliz revolución acometida”. Sin embargo, las presiones y reconvenciones que merecieron sus editoriales fueron tantas que se vio obligado a abandonar la iniciativa un año después. En 1853, apunta Furlong, El Diablo se quejaba de que "eran tantas las dentelladas que se habían dado a la libertad de prensa, que ya nada quedaba de la misma" y, en 1855, uno de los redactores de El Orden, Francisco Bilbao, fue llevado a los tribunales por el ministro Sarmiento. Esta enumeración no pretende ser minuciosa, sino que apunta a dejar constancia de la ingerencia del poder político sobre el ejercicio de la libertad de expresión, cuestión que mereció, en 1855, un firme editorial de Luis Domínguez, en el que afirmaba:

juzgamos muy necesaria una ley que clasifique los delitos que se cometen por la vía de la prensa y señale la pena que debe aplicárseles. Mientras eso no se haga, estaremos expuestos en los momentos apasionados, que se presentan muy a menudo en estos países, a presenciar los escándalos, que no han tenido poca parte en nuestras pasadas desgracias. ${ }^{87}$

De todos modos, durante estos años aquellos círculos opositores de la gestión gubernativa que contaban con un respaldo político suficiente en el nivel institucional, compartían el acuerdo básico de defensa de los principios de la Revolución de Septiembre y habían conseguido un

${ }^{87}$ Levene, Historia, 1940, vol. I, p. 74. 
financiamiento apropiado no encontraron mayores dificultades para publicar sus periódicos. Por ejemplo, El Orden -que apareció entre julio de 1855 y diciembre de 1858- sostuvo una controversia más doctrinaria que política con El Nacional, periódico que ejerció, según Abad de Santillán, una influencia incontrastable durante la década y ofició como principal' censor nacional. Una acción mucho más firme en la oposición política al gobierno de Obligado fue desempeñada por $E l$ Uruguay, redactado por José Mármol y Miguel Valencia, que apareció el 2 de octubre de 1855, y La Constitución, editado por Antonio Sáenz, que polemizó con $E l$ Nacional y La Tribuna. En sus páginas Lorenzo Torres lanzó fuertes embates contra Mitre y Sarmiento, acusándolos de haber formado una "oligarquía de círculo". Entre el 11 de julio y el 29 de septiembre de 1857, Francisco Bilbao editó La Revista del Nuevo Mundo, publicación que quiso elevarse por encima de las pasiones en pugna, aunque no consiguió evitar la polémica con Sarmiento y desapareció rápidamente. ${ }^{88}$

También al amparo del favor oficial, los acuerdos políticos o el respaldo de las armas, los grupos opositores al liberalismo porteño consiguieron editar sus periódicos en Buenos Aires en distintos momentos de la década. El 1 de abril de 1852, el gobierno provisional de López y Planes decidió editar un "diario guber-

${ }^{88}$ Véase Furlong, "Periodismo", 1966, vol. II, pp. 199-200. Véase un índice de publicaciones de la época en Orziali, Prensa, 1893. También proveen de interesante información Enrique Arana, "La prensa nacional después de Caseros", El Diario, 15 de agosto de 1933; Beltrán, Historia, 1943; y Galván, Periodismo, 1944 . nativo", El Progreso, en sustitución de $L a$ Gaceta Mercantil rosista, cuya publicación se extendió hasta la Revolución de Septiembre. Un año después, el 20 de febrero de 1853 , durante el sitio de la ciudad, apareció en San José de Flores El Federal Argentino, periódico que abogaba en favor de la unidad nacional y descargaba sus ataques contra Sarmiento. Una vez derrotados los sitiadores, la imprenta que lo editaba fue adquirida por los hermanos Varela, quienes el 7 de agosto de ese mismo año comenzaron a publicar $L_{a}$ Tribu$n a$. Después de la derrota de Cepeda apareció fugazmente, durante los meses de febrero y marzo de 1860 , un nuevo diario, La Patria, comandado, entre otros destacados redactores, por Vicente F. López, Miguel Cané, Luis Domínguez y Marcelino Ugarte. Sin embargo, el emprendimiento se vio abortado a poco de comenzar la gestión gubernativa en la provincia de Bartolomé Mitre.

Según se ha indicado, la libertad de imprenta habría de ser una de las principales víctimas de la violencia y crudeza que adquirió la vida política de la provincia a partir de 1856. Las características de este cambio pueden comprobarse al reconstruir someramente la trayectoria de los redactores de los dos principales medios federales de Buenos Aires en este momento: La Reforma Pacífica, que apareció a fines de 1856, y fue redactado por Nicolás Calvo, y La Prensa, dirigido por Juan Francisco Monguillot, que apareció al año siguiente. En algún punto ambos periódicos recorrieron un camino similar al ser subvencionados por Urquiza, lo que, junto con su crítico discurso, les valdrá la imposición de sucesivas multas y condenas de ostracismo para sus redactores, hasta concluir respectivamente con su 
clausura transitoria y su cierre definitivo. Sin embargo, los matices y diferencias entre ambos ofrecen indicadores apropiados al momento de intentar reconstruir la lógica de la relación entre prensa y política en los años cincuenta.

La Reforma Pacífica apareció el 1 de diciembre de 1856 , dirigido por Nicolás Calvo. Se trataba de un periódico federal que levantaba como programa la pacificación y unificación nacionales:

Somos porteños, pero no hemos dejado de ser argentinos. Propagaremos la necesidad de la unión y la concordia entre los buenos que hayan sido federales o unirarios, predicando el olvido de antiguos odios políicos, porque creemos que el sistema de Rosas no tenía amigos ni en su familia.

La Reforma Pacífica obtuvo rápidamente un sólido prestigio provincial y nacional, y no tardó en convertirse en el principal referente periodístico del federalismo provincial. Por ese motivo, la persecución oficial sería larga y trabajosa. Si bien la crítica de Calvo hacia la gobernación provincial se descargó sistemáticamente desde un primer momento, los decibeles del antagonismo entre liberales y federales porteños se fueron incrementando con el paso del tiempo. En 1859, Calvo desplegó una campaña de denuncia sobre la ingerencia del gobierno de Alsina en las elecciones del mes de marzo, que coronó con un artículo en el que exigía a sus lectores: "Si nos matan alevosamente, que lo maten a él [Alsinal como puedan."

A causa de este editorial, Calvo fue acusado por el fiscal de incitar a la muerte del gobernador. Según apunta Ricardo

${ }^{89}$ Levene, Historia, 1940, vol. I, p. 423.
Levene, el 3 de abril se publicó en el mismo periódico una nota (firmada entre otros por los generales Iriarte, Escalada, Pirán, coronel Tejerina, el presbítero Marín, Miguel Navarro Viola, Bernardo de Yrigoyen y Federico Pinedo), en la que se le solicitaba a Calvo, "en nombre de las conveniencias del partido a que pertenecen, no asistir al Juri que le ha promovido el fiscal del gobierno"..$^{90} \mathrm{La}$ mayor parte de los firmantes había tenido un papel fundamental en la Revolución de Septiembre y en la consolidación del acuerdo entre liberales y federales que dio vida a la repíblica de la opinión. El gobierno, en acuerdo de ministros, suspendió o destituyó a la mayoría de quienes desempeñaban cargos públicos, acusándolos de haberse hecho solidarios con "doctrinas de venganza y de sangre". Mientras tanto, la justicia le fijó a Calvo una multa de 2000 pesos, que fue abonada con el producto de una "suscripción patriótica" organizada entre sus lectores, quienes expresaron públicamente su profundo desacuerdo con la sanción. Las listas de los suscriptores fueron publicadas por el periódico, que los calificó como "patriotas". 91

Los ataques contra La Reforma Pacífica no terminaron allí, ya que, poco después, fue objeto de una nueva sanción por 10000 pesos, y su redactor Juan José Soto -quien había sucedido a Calvo-, fue condenado a seis meses de prisión efectiva. Finalmente, la justicia porteña suspendió el periódico por el plazo de 180 días, en el mes de junio de 1859, alegándose la comisión de complicidad con Urquiza. Sin embargo, esta sanción no llegó a cumplirse en su totalidad, ya que tras la bata-

${ }^{90}$ Ibid., p. 424.

${ }^{91}$ Citado en Auza, Periodismo, 1978, p. 175. 
lla de Cepeda el periódico iniciaría su segunda época, bajo la dirección de Nicolás Calvo.

En el caso de La Prensa, en cambio, el trayecto fue sustancialmente diferente. $\mathrm{Al}$ tratarse de un medio sin mayor inserción en la opinión pública local, ya que expresaba ante todo el deseo de Urquiza de difundir sus posiciones entre la opinión porteña, el periódico no conseguiría remontar la gravosa situación a que lo sometió la fijación de una multa de 8000 pesos, inhabilitación por 16 meses y destierro por cuatro años para su editor, por "artículos abusivos a la libertad de imprenta", en el mes de marzo de 1858. Los argumentos utilizados por el fiscal general Rufino de Elizalde para sostener que $L a$ Prensa había incurrido en abuso de la libertad de prensa no tienen desperdicio, y son una muestra irrefutable de la subordinación de la prensa a las reglas del juego político. En primer lugar, Elizalde denuncia que se trata de un periódico subvencionado por Urquiza, y que se inspira en sus intereses. A continuación señala que su prédica desacredita la libertad de prensa en Buenos Aires $y$, finalmente, que en sus páginas se califica como farsa a un juicio anterior, sostenido contra el mismo periódico. Invocando estas razones, Elizalde solicitó la convocatoria del jurado, cuya condena pondría fin a la experiencia de La Prensa en Buenos Aires en los años $1850 .^{92}$

${ }^{92}$ Archivo Elizalde, leg. 3, f. 2611. Por entonces, Nicolás Avellaneda hacía la siguiente reflexión, en carta a Posse: "Anduvo poco avisado Monguillot, dejándose llevar a este terreno, pues en vez de descender al fondo de la cuestión, explicando cuán mal entendidos son los intereses que alejan a Buenos Aires de las provincias, se empeñó en hacer el panegírico de
Los ejemplos de La Reforma Pacífica y de La Prensa permiten constatar la decisión de la dirigencia liberal de la república de la opinión de subordinar a la prensa a las exigencias del juego político, y limitar severamente el ejercicio del disenso. La Prensa ofrece un claro ejemplo al respecto: un periódico opositor, producto del interés de Urquiza por intervenir en el proceso de formación de la opinión pública en Buenos Aires, será drásticamente suprimido, pese a no haberse caracterizado por el ejercicio del libelo. El escaso respaldo otorgado por la opinión pública a $L a$ Prensa lo expuso sin contemplaciones a la acción institucional, que lo ahogó financieramente hasta forzarlo a desaparecer. La Reforma Paífica, en tanto, experimentó un proceso bastante diferente. En este caso se trataba de un periódico prestigioso, con una profunda inserción en la opinión pública porteña y una elevada consideración dentro del Partido Federal, que desde un primer momento desplegó una ácida crítica respecto de la acción de la dirigencia liberal, acusándola reiteradamente de manipular las instituciones públicas en su beneficio. Sin embargo, debido a su arraigo en la sociedad porteña, la dirigencia liberal encontró dificultades para imponerle sanciones, que, en definitiva, podían ser interpretadas como una confirmación de la ácida crítica de Calvo, pese a que éste echaba mano crecientemente a expresiones

Urquiza y su gobierno, lo que ha resultado contraproducente en este ambiente caldeado por los partidos que tanta tenacidad ponen en sus odios. Los Debates, La Tribuna, idealizan la situación de Buenos Aires, haciéndola proyectar sombras ofensivas sobre las demás provincias, pues el reverso del cuadro hace inevitable presentarlas extenuadas y pobres bajo la bota del caudillo." Avellaneda, Escritos, 1974, p. 55. 
y juicios que, en el pasado, habían sido utilizados por los poderes públicos para gravar o disciplinar a otros medios gráficos. Haría falta que su redactor aceptara el auxilio financiero de Urquiza y recurriera a la amenaza directa sobre la vida del gobernador, en el contexto de creciente fragor bélico que desembocaría, pocos meses después, en la batalla de Cepeda, para que la administración se decidiera a impulsar las primeras sanciones.

La respuesta de los lectores y allegados a Calvo, quienes participaron de una "suscripción patriótica" para abonar la multa fijada por el tribunal público, significó una nueva demostración del respaldo que una porción significativa de la opinión pública otorgaba al joven Calvo y a su aguerrido periódico. Esta especie de pronunciamiento popular tuvo un impacto mucho más limitado de lo que podría suponerse, como consecuencia de la turbulencia que experimentaba la relación entre Buenos Aires y la Confederación. En este contexto, la administración hizo caso omiso del consenso popular que rodeaba el periódico, y propulsó la imposición de nuevas multas y suspensiones. En definitiva, las sanciones no llegarían a cumplirse en su totalidad, ya que la victoria militar de las fuerzas de la Confederación aportó las condiciones indispensables para una reaparición anticipada del periódico.

El liberalismo a la defensiva: las secuelas de Cepeda

Tras la derrota de las fuerzas de Buenos Aires en la batalla de Cepeda, en 1859 los acuerdos celebrados con Urquiza dispusieron la convocatoria de una Convención provincial encargada de presentar una serie de propuestas para una eventual modificación del articulado de la Constitución de 1853, las que deberían ser discutidas por una Convención Reformadora nacional. Entre las cuestiones sobre las que los legisladores hicieron hincapié en la convención de Buenos Aires se destacó la referida a la libertad de imprenta. A ese respecto, el proyecto de la Comisión respectiva, presentado a consideración de la Convención el 1 de mayo de 1860, disponía: "Art. El Congreso federal no dictará leyes que restringen la libertad de imprenta, o establezcan sobre ella la jurisdicción federal."

Esta iniciativa fue sostenida con rigor por Dalmacio Vélez Sársfield:

La reforma importa decir que la imprenta debe estar sujeta a las leyes del pueblo en que se use de ella. Un abuso de la libertad de imprenta nunca puede ser un delito, diré así, nacional. El Congreso dando leyes de imprenta sujetaría el juicio de los tribunales federales, sacando el delito de su fuero natural. La reforma dice aún más; que el Congreso no puede restringir la libertad. La libertad de imprenta, señores, puede considerarse como una ampliación del sistema representativo o como su explicación de los derechos que queda al pueblo, después que ha elejido sus representantes al Cuerpo Legislativo. Cuando un pueblo elije sus representantes no se esclaviza a ellos, no pierde el derecho de pensar o de hablar sobre sus actos; esto sería hacerlos irresponsables. Él puede conservar y conviene que conserve, el derecho de examen y de crítica para hacer efectiva las medidas de sus representantes y de todos los que administren sus intereses. $\mathrm{O}$ si no preguntad a todos los opresores del pueblo, ¿cuál es el primer medio que emplean para 
dominarlos a su arbitrio? ¡Quitar la libertad de imprenta o ponerle pesadas restricciones! ${ }^{93}$

La intervención de Vélez Sársfield revistió un carácter canónico: allí mismo se cerró el debate y su tesis fue aprobada sin inconvenientes. Sin embargo, la contundencia y coherencia de la intervención del jurista cordobés no alcanzaba a ocultar que los argumentos desplegados en su exposición se distanciaban significativamente de aquellos que habían prevalecido en la república de la opinión, sobre todo a partir de 1857. En efecto, si bien no se observan contradicciones en cuanto a la asignación de una dimensión provincial a la cuestión de la fijación de los criterios y jurisdicciones referidas a la cuestión de la libertad de prensa, Vélez Sársfield aboga en favor de la vigencia de una libertad de imprenta absoluta, en tanto le asigna el carácter de correctivo fundamental para garantizar la responsabilidad de los representantes. La libertad de prensa resulta esencial, para Vélez Sársfield, para garantizar la creación del "gran poder que gobierna a los pueblos y dirige a los gobernandos: la opinión pública". En su intervención -que recupera la matriz fundante del discurso de la legitimidad de tiempos de las Jornadas de Junio-, Vélez Sársfield recusa de plano la posibilidad de que los abusos de la prensa puedan derivar en trastornos sociales, adjudicando el padrinazgo de ese razonamiento a los gobiernos que intentaban valerse de él como excusa para reprimir el renacimiento de la libertad de un pueblo, producto de la consagración de los derechos individuales. De este modo, concluye afirmando que la fijación de pesadas restricciones al ejer-

${ }^{93}$ Convención, Diario, 1859-1860, pp. 191-193. cicio de la prensa, o la liquidación de la libertad de imprenta, son los recursos utilizados por todos los opresores del pueblo para dominarlo a su arbitrio. Evidentemente, éstos no eran los criterios que habían prevalecido en la república de la opinión, y que habían llevado a sancionar la "ley bárbara" de imprenta de 1857. Por el contrario, la preocupación ante el avance del poder de un Estado -en este caso, nacional-sobre el que no se ejercía un control efectivo, sobre la libertad de imprenta, parece haber decidido al liberalismo provincial a restañar sus viejas banderas en defensa de una amplia libertad de expresión, a similitud de lo sucedido en el marco de las Jornadas de Junio.

Los argumentos expuestos por Vélez Sársfield coinciden en lo esencial con los presentados por Sarmiento, en el marco de la Convención provincial encargada de proponer las reformas constitucionales. En este caso, el polifacético Sarmiento, desplazado momentáneamente del gobierno provincial, destacará el carácter de correctivo fundamental que significaba la prensa para evitar el despotismo y los abusos de autoridad por parte de los representantes. Para ello, los argumentos que asociaban al libelo con el delito común y que habían sido la base de la ley de imprenta de 1857 fueron silenciados. Como nadie, el sanjuanino reflejaba las dos caras que presentaba el liberalismo político nativo, ya fuese que se encontrara ejerciendo el gobierno o en la oposición. ${ }^{94}$

94 "Pero hay otro punto capital, y es la responsabilidad personal de representante. No hay acción pública que pueda ejercerse sin responsabilidad. El despotismo no es más que la libertad de un hombre para hacer su voluntad sin responsabilidad ninguna. El diputado ejerce una tiranía cuando no tiene responsa- 


\section{Subsidios y lealtades}

En los acápites anteriores se ha demostrado que, a lo largo de la década de 1850 , la prensa porteña estuvo subordinada a la lógica del juego político. Lejos de resultar un emergente de la sociedad civil capacitado para ejercer funciones de control sobre el ejercicio del poder político, la prensa adoptó una lógica profundamente facciosa, que condicionó -o directamente impidió- la emisión de discursos críticos alternativos que pusieran en cuestión las bases del sistema o la legitimidad de los representantes y gobernantes. Para completar mi estudio sobre las vigencia de la libertad de prensa y las posibilidades de ejercicio del disenso en la república de la opinión, a continuación estudiaré algunos aspectos pendientes de la relación entre la prensa y el poder político en la década de 1850 .

A mediados de 1855, un Sarmiento recientemente retornado a Buenos Aires expresaba a su amigo Posse su alegría por haber sido designado jefe de Escuelas y, casi simultáneamente, redactor de $\mathrm{El} \mathrm{Na}$ cional. El sanjuanino tenía en claro que tales nombramientos habían sido posibles por su pertenencia al círculo liberal liderado por Valentín Alsina y Bartolomé Mitre. De este modo, un adecuado alineamiento dentro del universo faccioso había sido la clave de acceso al empleo, tanto público como privado. ${ }^{95}$ Pocos días después, Sarmiento enviaba una nueva carta a Posse para solicitarle que le recomendara un corresponsal para El Nacional. Ob-

bilidad de sus actos. En las sociedades occidentales, la prensa ha sido la encargada de hacerles ver sus desaciertos, y de encaminarlos por la senda correcta." Ibid., p. 203.

95 Véase Paoli, Samiento, 1973, pp. 139-140. sérvese el perfil que el sanjuanino requería para su nuevo empleado: "Es preciso que el corresponsal crea mediocremente en la libertad posible y poco en los caudillos. Sobre todo que sea desafecto a Urquiza a fin de que no muestre las cartas." 96

Los criterios de elegibilidad de Sarmiento coinciden, ciertamente, con la caracterización que por esos días formulaba Alberdi sobre la prensa en Argentina: el territorio nacional estaba dividido entre dos gobiernos, que sólo estaban dispuestos a tolerar una amṕlia libertad de imprenta en tanto los redactores se aplicaran a denostar al adversario y a halagar a las autoridades e instituciones propias. Ambos bandos asignaban a la prensa un papel esencial para la consolidación de su poder de autoridad, por lo que la formación de la opinión pública era uno de los principales ítems que incluía su estrategia política. Más arriba se han estudiado los aspectos coercitivos de esas estrategias, vinculados con la sanción de nuevas herramientas legales para el control del disenso a través de la prensa. Entre estos recursos podría incluirse, asimismo, el proyecto de Ley de Correos de 1858. En este caso, la propuesta del gobierno fijaba un impuesto a la distribución de impresos en la campaña, con la finalidad nada ingenua -según se le enrostrará durante el debatede restringir la circulación de periódicos, propiciando su ahogo financiero. $\mathrm{Al}$ respecto, debe recordarse que en la campaña, justamente, tenían gran circulación las publicaciones de los federales reformistas, en especial La Reforma Pacífica de Nicolás Calvo. Sin embargo, la ingeniosa iniciativa fue invalidada por uno de los propie-

${ }^{96}$ Sarmiento a Posse, 15 de julio de 1855, en Museo Histórico Sarmiento, leg. 5, núm. 523. 
tarios de La Tribuna, Héctor Varela, y por Rufino de Elizalde, quien se negó a reconocer en ella más que un inaceptable afán recaudador:

Creo que las ventajas que se reportarían en la campaña de dejar libre la circulación de los diarios, en el sentido moral de difundir la lectura de los periódicos, es inmensamente mayor que la poca renta que se va a recibir pór este impuesto. ${ }^{97}$

Aunque convencionales, los argumentos vertidos permiten teafirmar la confianza de la dirigencia liberal en el papel de la prensa como formadora de opinión en el marco de la república de la opinión. En realidad, lo que Elizalde afirma es que la escasa recaudación que promete un impuesto como el propuesto, de poca monta, no alcanza para resarcir el daño que la disminución en la circulación de periódicos en la campaña podría causar. Lo que le preocupaba a Elizalde era el daño moral que implicaba adoptar una medida que dificultaba el acceso de una porción significativa de la población - que no se contaba mayoritariamente entre la base política del liberalismo- a los medios formadores de opinión por excelencia, los periódicos, que por entonces, según se ha estudiado en el ítem inicial de este capítulo, desempeñaban una función estatal de integración de la población "bárbara" a los códigos y valores de la "civilización". Así, su argumento no implicaba una defensa abstracta de la libertad de imprenta, sino un frío cálculo de los daños que podría significar un alejamiento de esa masa rural de la interpelación de los periódicos de

979 de agosto de 1858 en Cámara de Senadores, Diario, 1854-1861, p. 406.
Buenos Aires. Siguiendo con este razonamiento, lo realmente preocupante para el liberalismo porteño era que la campaña fuera lectora de La Reforma Pacífica, y ésta era, precisamente, la situación que debería ser modificada.

En ese sentido puede leerse el reclamo formulado un año después por Mariano Varela a Rufino de Elizalde, quien para entonces se desempeñaba como fiscal provincial. Asimismo, la nota de Varela permite comprobar que los periódicos, lejos de asumir una defensa de la autonomía periodística y de la libertad de expresión, respondían a una lógica estrictamente facciosa, que no omitía solicitar la intervención de Estado para solucionar sus propias rivalidades. "Si yo tuviera influencia con usted le pediría que acusase La Reforma que presta sus columnas a un muchacho sin reflexión, para que cometa delitos, pues es un delito lo que ha hecho. Mañana yo pienso escribir en La Tribuna al respecto."98

De todos modos, el hecho de que un modesto impuesto a la circulación de impresos en la campaña pudiera ser considerado como una estrategia válida para afectar la distribución de la prensa opositora y, con ello, dañar una de sus principales fuentes de financiamiento -la suscripción-, constiruye un indicador de la precaria situación financiera que debió afrontar el periodismo durante la década. Justamente, esa debilidad intrínseca de la prensa fue aprovechada por el poder político para establecer un sistema de intercambio de subsidios por lealtades políticas, que

98 El 27 de junio de 1860, en Archivo Elizalde, pp. 523-524. Esta práctica continuará en las décadas de 1860 y 1870 . Al respecto, véanse Lettieri, "Construcción", 1995 y "Formación", 1993. 


\section{SECUENCIA}

TO BE WITHIN ARM'S REACH OF DISTANT "COUNTRIES IT IS ONLY NECESSARY TO BE

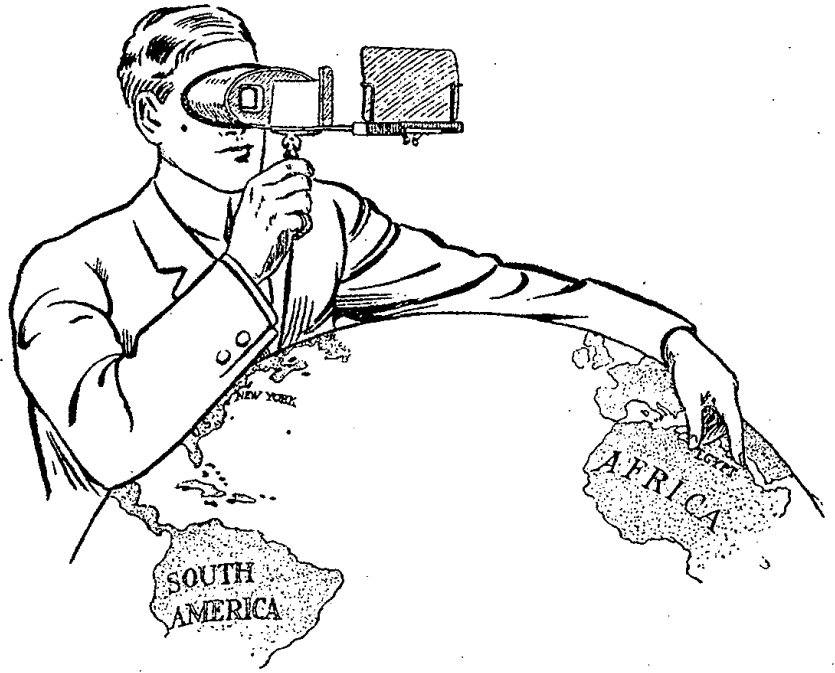

WTTHIN ARM'S REACH OF THE UNDERWOOD STERROGRAPH-TRAVEL SYSTEM 
le permitió no solamente garantizarse la subordinación de buena parte de la prensa provincial, sino - fundamentalmente- el control de los juicios vertidos en el proceso de formación de la opinión pública. En efecto, los fondos públicos corrieron de manera generosa para garantizar la consolidación del consenso de la opinión pública, en el marco del proceso de construcción de un poder de autoridad. Evidentemente, esta compleja y estrecha relación establecida entre editores y poder político, satisfaciendo intereses mutuos, alentó en buena medida la vigencia de esa autocensura que Alberdi prefería al ejercicio de la coerción directa. En tal sentido, la carta enviada por Valentín Alsina a su ministro Bartolomé Mitre, el 25 de abril de 1858 , referida a la solicitud de La Crónica de que el gobierno contratara una generosa suscripción de ejemplares, resulta muy significativa:

Sabe usted que el fondo anual para suscripciones e impresiones es solamente 240000 pesos. El gobierno está suscrito hoy a La Tribuna (por contrato), El Nacional, Los Debates, British Packet, Espada, Regeneracion, Opinión Pública, Aniceto, Comercial Times, Mosaico Poético, la obra de Núñez, Celebridades y qué se yo cuantas otras ( $\mathrm{y}$ no hablo aquí de [impresiones]; de modo que aun sin contar las nuevas suscripciones que sean [forzosas] en el resto del año, es muy difícil que alcance la suma. ${ }^{99}$

Pese a las consideraciones de Valentín Alsina, los editores de La Crónica obtuvieron una suscripción de 100 ejemplares por tirada. No sería ésta, por cierto, una práctica inaugurada por esta gestión. En

${ }^{99}$ En Auza, Periodismo, 1978, pp. 197 y ss. efecto, ya en 1854, en tiempos de la gobernación de Obligado, el mismo periódico había sido beneficiado con la compra de 60 ejemplares, propuesta por el obispo Aneiros y aprobada por la flamante Legislatura provincial. ${ }^{100}$ Sobre el particular, el cariz de la nota enviada por Félix Frías y Luis Domínguez al oficial mayor del Ministerio de Guerra y Marina en 1855, durante la gestión de Pastor Obligado, para solicitar una suscripción oficial para el periódico El Orden, desnuda por sí sola la relación de subordinación y dependencia financiera del gobierno provincial que experimentaba la mayor parte de la prensa porteña. Los firmantes señalaban que, en su calidad de redactores de

El Orden, estaban dispuestos a hacer las publicaciones oficiales como habían convenido con los ministros de Gobiemo y de Hacienda. Es entendido que $E l$ Orden continuará siendo fiel a sus principios moderados y conservadores, y aunque no será un órgano del gobierno, tampoco insertará en sus columnas, como no ha insertado hasta ahora, ataques $u$ ofensas a la administración que contratíen su marcha. ${ }^{101}$

$\mathrm{El}$ intercambio de subsidios por lealtades alcanzó niveles llamativos. A lo largo de la década de 1850. Por ejemplo, la difusión de esta práctica fue el argumento utilizado por el legislador Agrelo, en 1855 , para solicitar la asignación de fon-

100 "Art. único. Autorízase al presidente de la Cámara de Diputados para suscribirse por 60 ejemplares al periódico La Crónica que publica las sesiones de ambas Cámaras", 25 de agosto de 1854, en Cámara de Diputados, Diario, 1854-1861, p. 197.

101 Véase Heras y Barba, "Relaciones", 1947, pp. 225 y ss. 
dos para una publicación de leyes y decretos que estaban organizando los señores Ocantos y Villegas. La iniciativa fue aprobada sin discusión por las Cámaras: "Ya que la Cámara se está suscribiendo a toda clase de periódicos, yo haría moción para que se suscribiese a una cosa tal vez más importante, cual es la publicación de las leyes y decretos que están haciendo los señores Ocantos y Villegas." 102

Ciertamente, no faltaron las excepciones a esta práctica de intercambio de favores entre la administración y los periódicos. Según se ha estudiado en "La prensa política de Buenos Aires en la segunda mitad del siglo XIX", al principio de este artículo, en algunos casos, la imposibilidad de acceder al financiamiento oficial significó el fin de un emprendimiento periodístico; en otros, la ausencia de financiamiento oficial obligaba a los círculos -fundamentalmente opositores- a editar periódicos de corta vida, limitados a la duración de un proceso electoral. Justamente, para hacer notar su independencia de criterios respecto de las autoridades, el periódico La Ilustración, ${ }^{103}$ que contó entre sus redactores a Juan María Gutiérrez y comenzó a publicarse el 1 de marzo de 1854, decidió definirse como un "diario político, literario y comercial redactado por una sociedad de ciudadanos libres $\mathrm{e}$ independientes, que no reciben sueldos del Estado". Sin embargo, estos propósitos eran muy difíciles de sostener, razón por la cual los periódicos independientes del financiamiento estatal no consiguieron mantenerse durante mucho tiempo.

1026 de agosto de 1855 , Cámara de Senadores, Diario, 1854-1861, p. 231.

${ }^{103}$ La Ilustración, 1 de marzo de 1854.

\section{CONCLUSIÓN}

Durante el periodo comprendido entre las batallas de Caseros y de Pavón, la prensa porteña estuvo subordinada a la lógica del juego político. Las condiciones de posibilidad de las publicaciones, siempre dependientes de los fondos estatales, estuvieron signados por la evolución del delicado e inestable equilibrio que caracterizó a la vida política argentina en la década siguiente a la caída del rosismo.

El estricto control ejercido sobre la actividad periodística fue consecuencia de las amplias expectativas que le impuso la nueva elite dirigente dentro del proceso de construcción de un amplio consenso en la opinión pública, considerado como cemento esencial para la construcción de un sólido poder de autoridad.

Aun cuando no resulte posible afirmar que el objetivo de la elite política haya consistido en ahogar todo vestigio de la libertad de imprenta, la autonomía acordada a los redactores se mantuvo acotada dentro de los límites aceptados por el poder político para el ejercicio del disenso: esto es, libertad plena para atacar al adversario, pero amenaza cierta de clausura o sanción pecuniaria -incluso no debía descartarse la gravísima acusación de traición-ante cualquier expresión que fuera considerada agraviante por la coalición gobernante. El proyecto del liberalismo porteño, trenzado en una dura lucha por la recuperación de la hegemonía provincial a nivel nacional significó, en la práctica, un grave condicionamiento para la difusión de discursos y propuestas alternativas, situación que se profundizó a partir de la ruptura de su alianza con los rosistas porteños, en 1857. 
Los severos condicionamientos impuestos al ejercicio de la libertad de imprenta constituyeron fieles indicadores de la pretensión del Estado provincial de delinear una sociedad civil a su medida, en consonancia con una tradición estatal ya desplegada durante la primera mitad del siglo XIX en Río de la Plata, y que evidenciaba innegables marcas de la tradición colonial española. ${ }^{104}$ En tal sentido, resulta necesario consignar que esta pretensión modeladora de la sociedad civil evidenciada por el Estado no sólo afectó a la actividad periodística, sino que se manifestó también en el licenciamiento de la guardia nacional en $1853 ;^{105}$ la subordinación de la justicia provincial a las directivas del poder político, dispuesta por decreto del 8 de agosto de $1853 ;{ }^{106}$ la represión de diversas formas de sociabilidad popular, consideradas como "expresión de la barbarie" -las pulperías urbanas fueron las principales víctimas de tales ataques-; ${ }^{107}$ $y$ el ejercicio del fraude y la violencia electoral, ${ }^{108}$ que impidieron el desarrollo de una ciudadanía moderna a lo largo del periodo.

\section{ARCHIVOS}

Archivo Elizalde.

Museo Histórico Sarmiento.

${ }^{104}$ Al respecto, González, "Vida", 1999, pp. 55

y ss.; Myers, "Revolución", 1999, pp. 67 y ss.

${ }^{105}$ Véase Letrieri, Repríblica, 1999.

${ }^{106}$ Ibid.

${ }^{107}$ Véase González, Civilidad, 2002, pp. 286 y ss.

${ }^{108}$ Sabato, Política, 1998, 1a. parte.

\section{HEMEROGRAFÍA}

El Diario, 1933.

El Nacional, 1852-1861.

La Prensa, 1857.

La Ilustración, 1854.

La Tribuna, 1852-1861.

Los Debates, 1852, 1857-1858.

Nueva Revista de Buenos Aires, 1883.

\section{BIBLIOGRAFÍA}

- Abad de Santillan, Diego, Historia argentina, TEA, Buenos Aires, t. 3, 1965.

- Alberdi, Juan Bautista, Obras completas, Ateneo, Buenos Aires, 1917, t. vi.

- Cartas quillotanas, Claridad, Buenos Aires, 1932.

—_, Derecho público provincial, Companía General de Fósforos, Buenos Aires, 1918.

-Alonso, Paula, "En la primavera de la historia'. El discurso político del roquismo de la década del ochenta a través de su prensa", Boletín del Instituto de Historia Argentina y Americana Dr. Emilio Ravignani, 3a. serie, núm. 15, ler. semestre de 1997, Buenos Aires.

- Entre la revolución y las urnas. Los origenes de la Unión Cívica Radical y la política argentina en los años 90, Sudamericana/Universidad de San Andrés, Buenos Aires, 2000.

- Álvarez, J. y A. Martínez Riaza, Historia de la prensa bispanoamericana, Mapfre, Madrid, 1992.

-Anderson, Benedict, Imagined Communities: Reflections on the Origin and Spread of Nationalism, Verso/New Left Books, Londres, 1983.

- Auza, Néstor, El periodismo de la Confederación, 1852-1861, Belgrano, Buenos Aires, 1978.

-Avellaneda, Nicolás, Escritos literarios, Kapelusz, Buenos Aires, 1974.

-Beltrán, Óscar R., Historia del periodismo argentino, Kraft, Buenos Aires, 1943. 
-Cámara de Diputados de la Legislatura de la Provincia de Buenos Aires, Diario de sesiones, s. e., Buenos Aires, 1854-1861.

-Cámara de Senadores de la Legislatura de la Provincia de Buenos Aires, Diario de sesiones, s. e., Buenos Aires, 1854-1861.

-Cárcano, Ramón J., De Caseros al 11 de septiembre, Buenos Aires, Compañía General de Fósforos, 1918.

—_ "La reorganización del país después de Caseros" en Academia Nacional de la Historia, Historia de la Nación Argentina, El Ateneo, Buenos Aires, 1947, vol. vin.

-Cibotti, Ema, '“El Mosquito' de Enrique Stein, un ejemplo de periodismo faccioso en la década del 80", 4as. Jomadas Interescuelas de Historia, U. N. de Mar del Plata, Mar del Plata, mimeo., 1993.

- "Sufragio, prensa y opinión pública: las elecciones municipales de 1883 en Buenos Aires" en Antonio Annino (coord.), Historia de las elecciones en Iberoamérica, FCE, México, 1995.

- Convención Reformadora de la Constitución Nacional de la Provincia de Buenos Aires, Diario de sesioner, s. e., Buenos Aires, 1859-1860.

-Duncan, Tim, "La prensa política: 'SudAmérica', 1884-1892” en G. Ferrari y E. Gallo (comps.), La Argentina del ochenta al centenario, Sudamericana, Buenos Aires, 1980.

-Eujenian, Alejandro, "La cultura: público, autores y editores" en M. Bonaudo (dir.), Liberalismo, estado y orden burgués (1852-1880), Sudamericana, Buenos Aires, 1999, t. IV (Nueva Historia Argentina).

-Furlong S. J., Guillermo, "El periodismo entre los años 1860 y 1930 " en Academia Nacional de la Historia, Historia de la nación argentina, Desde los orígenes hasta 1862, vol. II, 2a. sección, Historia de las Instituciones y la Cultura, EI Ateneo, Buenos Aires, 1966.

-Galván Moreno, Carlos, El periodismo argentino, Kraft, Buenos Aires, 1944.
-Goldman, Noemí, "Libertad de imprenta, opinión pública y debate constitucional en el Río de la Plata (1810-1827)", Prismas, núm. 4, Universidad Nacional de Quilmes, 2000.

-González Bernaldo, Pilar, "Vida privada y vínculos comunitarios: formas de sociabilictad popular en Buenos Aires, primera mitad del siglo XIx" en F. Devoro y M. Madero (dirs.), Historia de la vida privada en la Argentina, t. 1, País antiguo. De la colonia a 1870, Taurus, Buenos Aires, 1999.

- Civilidad y política en los orígenes de la Nación argentina, FCE, Buenos Aires, 2002.

-Guetra, François-Xavier, "Hacia una nueva historia política. Actores sociales y actores políticos", Anuario IEHS, núm. 4, 1989.

-Gunn, J.A.W., Beyond Liberty and Property, Montreal, Queen's University Press, 1968.

-Halperin Donghi, Tulio, José Hernández y sus mundos, Sudamericana, Buenos Aires, 1987.

-Heras, Carlos y Enrique Barba, "Relaciones entre la Confederación y el Estado de Buenos Aires" en Academia Nacional de la Historia, Historia de la nación argentina. Desde los orígenes hasta 1862, El Ateneo, Buenos Aires, 1947.

-Lettieri, Alberto R., "Formación y disciplinamiento de la opinión pública en los inicios del sistema político moderno. Argentina, 1862 1868", Entrepasados, año IV, núm. 6, 1994.

- L La formación del sistema político moderno. Legitimidad, opinión pública y sistema politico. Argentina, 1862-1868, FFyL-UBA, Buenos Aires, 1995 (Cuadernos de Investigación del Instituto Ravignani 8).

- Vicente Fidel López. La construcción bistórico-politica de un liberalismo conservador, Biblos-Fundación Simón Rodríguez, Buenos Aires, 1995.

—_, "La construcción del consenso en los inicios del sistema político moderno argentino, 1862-1868", Anuario de Estudios Americanos, vol. LIl, núm. 2, 1995, Sevilla. 
- L_ La república de la opinión. Política y opinión pública en Buenos Aires en la década de 1850, Biblos, Buenos Aires, 1999.

"De la república de la opinión a la república de las instituciones", en M. Bonaudo (dir.), Liberalismo, estado y orden burgués (1852-1880), Sudamericana, Buenos Aires, 1999 (Nueva Historia Argentina, Iv).

- La república de las instituciones. Proyecto, desarrollo y crisis del proyecto político liberal en la Argentina en tiempos de la organización nacional, El Quijote, Buenos Aires, 2000.

- La civilización en debate. Historia contemporánea: de las revoluciones burguesas al neoliberalismo, Eudeba, Buenos Aires, 2003.

- La civilización en debate. Historia contemporánea de las revoluciones burguesas al neoliberalismo, Eudeba, 1a. ed., Buenos Aires, 2003; Prometeo, 2a. ed., Buenos Aires, 2004.

- Seis leciones de política, Prometeo, Buenos Aires, 2004.

-Levene, Ricardo (dir.), Historia de la provincia de Buenos Aires y formación de sus pueblos, Publicaciones del Archivo Histórico de la Provincia de Buenos Aires-Taller de Impresiones Oficiales, La Plata, 1940, vol. I.

-Myers, Jorge, Orden y virtud. El discurso republicano en el régimen rosista, Universidad $\mathrm{Na}$ cional de Quilmes, Bernal, 1995.

- "Una revolución en las costumbres: las nuevas formas de sociabilidad de la elite porteña, 1800-1860" en F. Devoto y M. Madero (dir.), Historia de la vida privada en la Argentina, t. 1, País antiguo. De la colonia a 1870 , Taurus, Buenos Aires, 1999.

-Navarro Viola, N., Anuario de la prensa argentina, 1896, Imprenta del Mercurio, Buenos Aires, 1897.

-Orziali, Ignacio, La prensa argentina, Imprenta, litografía y encuadernación de Jacobo Peuser, Buenos Aires, 1893.
-Ozouf, Mona, "L'opinion publique" en K. M. Baker (ed.), The French Revolution and the Creation of Modern Political Culture, CNRS, Oxford, 1987, 3 vols.

-Palti, Elías, "La historia de Belgrano de Mitre y la problemática concepción de un pasado nacional", Boletín del Instituto de Historia Argentina y Americana Dr. E. Ravignani, 3a. serie, núm. 19, FFyL-UBA/FCE, 1er. semestre de 1999.

-Paoli, P. de, Sarmiento, ese desconocido, Theoría, Buenos Aires, 1973.

-Pye, Lucian W., Evolución política y comunicación de masas, Troquel, Buenos Aires, 1969.

-Ramos, Julio, Desencuentros de la modernidad en América Latina. Literatura y política en el siglo XIX, FCE, México, 1989.

-Quesada, Ernesto, "El periodismo argentino", Nueva Revista de Buenos Aires, t. Iv, 1883 , Buenos Aires.

-Sabato, Hilda, La politica en las calles. Entre el voto y la movilización, Buenos Aires, 1862-1880, Sudamericana, Buenos Aires, 1998.

-Sabato, Hilda y Ema Cibotti, "Hacer política en Buenos Aires: los italianos en la escena pública porteña, 1860-1880", Boletín del Instituto de Historia Argentina y Americana Dr. E. Ravignani, 3a. serie, núm. 2, FFyL-UBA/FCE, ler. semestre de 1990.

-Sabato, Hilda y Alberto Lettieri, La política en la Argentina del siglo XIX. Armas, votos y voces, FCE, Buenos Aires, 2003.

-Sala de Representantes de la Provincia de Buenos Aires, Diario de sesiones, s. e., Buenos Aires, 1852-1854.

-Saldías, Adolfo, Un siglo de instituciones, Hyspamérica, Buenos Aires, 1987, t. II.

-Shils, Edward, "Demagogos y cuadros en el desarrollo político de los nuevos Estados" en Lucian W. Pye, Evolución politica y comunicación de masas, Troquel, Buenos Aires, 1969. 